\title{
Remains from a Demolished Cultural Heritage: A Historical House in
}

\section{Karaagac}

\author{
Yıkılan Bir Kültür Mirasının Ardından Kalanlar: Karaağaç'ta Tarihî Bir Ev
}

\section{Gamze Fahriye Pehlivan* (1)}

\begin{abstract}
Reflecting the historical, cultural and sociological characteristics of an era, historical houses are one of the building blocks of society's identity. However, today it is observed that these buildings were abandoned for various reasons and then demolished due to the lack of maintenance. The example examined in this article is a traditional house that was documented ten years ago and demolished in a later period. The building which contains the general characteristics of the traditional residential architecture in Karaagac consists of a basement and ground floor. Built in the nineteenth century, the house consists of a gable roof covering the rectangular plan (inner sofa plan type) with a backyard and extension. In the $21^{\text {st }}$ century, historical buildings have been abandoned because of some reasons such as, not meeting the changing needs for housing, heirs' not compromising, not being able to compensate maintenance and repair cost. After their abandonment, it was determined that the building was destroyed and then its wreck was removed. It is suggested to use cultural heritage for preventing them from facing this situation in this study. Because a cultural heritage requires continuous maintenance and repair, a sustainable preservation will be needed.
\end{abstract}

With this study, it is aimed to bring the remaining data of a destroyed cultural heritage into the literature and to determine what needs to be done before reaching the demolition process. The second aim is to encourage a sustainable preservation of the cultural heritage while considering preservation-usage balance. In this article, literature review is used as a method. The material of this study consists of building survey, building survey report and photographs of the traditional house.

\section{Keywords}

Adaptive reuse, cultural heritage, Karaagac architecture, preservation, traditional house

\section{Öz}

Bir dönemin tarihî, kültürel ve sosyolojik özelliklerini yansıtan tarihî evler, toplumun kimliğini oluşturan yapı taşlarından biridir. Bazı tarihi evlerin günümüzde çeşitli sebeplerle terk edildiği, daha sonra da bakımsızlıktan yıkıldığı gözlemlenmektedir. Makalede incelenen örnek on yıl önce belgeleme çalışmaları yapılan ve sonraki bir dönemde yıkılan geleneksel bir konuttur. Karaağaç’taki geleneksel konut mimarisinin genel özelliklerini barındıran yapı, bodrum ve zemin kattan oluşmaktadır. 19. yüzyılda inşa edilen konut, iç sofalı plan tipine sahip, arka bahçesi ve müştemilatı olan, dikdörtgen planın üzerini örten beşik çatıdan meydana gelmiştir. 21. yüzyılda değişen konut ihtiyaçlarını karşılayamama, göç, mirasçıların uzlaşamaması, bakım ve onarım masraflarının karşılanamaması vb. sebeplerle yapı, terk edilmiştir. Terk edilişinden bir süre sonra yapının yıkıldığı ve daha sonrasında molozunun kaldırıldığı tespit edilmiştir. Bu çalışmada, kültür miraslarının bu durumla karşı

* Correspondence to: Gamze Fahriye Pehlivan (Asst. Prof. Dr.), Sivas Cumhuriyet University, Department of Architecture, Sivas, Turkey. E-mail: geraybat@hotmail.com ORID: 0000-0001-5293-863X

To cite this article: Pehlivan, Gamze Fahriye. "Remains from a Demolished Cultural Heritage: A Historical House in Karaagac." Art-Sanat, 15(2021): 249-285. https://doi.org/10.26650/artsanat.2021.15.0011 
karşıya kalmasını önlemek amacıyla kullanılarak yaşatılması önerilmiştir. Kullanılan bir kültür mirasının sürekli bakım ve onarımı yapılacağından korumada sürdürülebilirlik sağlanacaktır.

Bu çalışmayla, yıkılan bir kültür mirasının elde kalan verilerini literatüre kazandırmak hedeflenmektedir. İkincil hedef de kültür miraslarımızın sürdürülebilir korunması için koruma-kullanım dengesini gözeterek kullanımasını teşvik etmektir. Bu makalede, literatür taraması yönteminden faydalanılmıştır. Bu çalışmanın malzemesini, geleneksel konutun rölövesi, rölöve raporu ve fotoğrafları oluşturmaktadır.

Anahtar Kelimeler

Uyarlanabilir yeniden kullanım, kültürel miras, Karaağaç mimarisi, koruma, geleneksel ev

\section{Genișletilmis Özet}

Toplumun gelenek ve göreneklerini yansıtan, gündelik yaşamdan kesitler sunan geleneksel konutlar, taşıdığı değerler sebebiyle korunması gerekli kültür varlıklarıdır. $\mathrm{Bu}$ kültür varlıklarından bazılarının zamanla kullanılamaz hâle geldiği ve sonrasında da yıkıldığı gözlemlenmektedir. Bu örneklerden biri de Edirne'nin Karaağaç Mahallesi'nde 866 ada, 10-11 numaralı parselde yer alan tescilli geleneksel konuttur. 2009 yılındaki belgeleme çalışmaları kapsamında, konutun rölövesi, rölöve raporu ve fotoğraf albümü hazırlanmıştır. Bundan on yıl sonra, alanda yapılan incelemelerde, yapının yerinde olmadığı ve sadece yapının izlerinin kaldığı tespit edilmiş ve bu tespitler fotoğraflanarak belgelenmiştir. Bu veriler, çalışmanın malzemesini oluşturmaktadır.

Bu makalede, yöntem olarak literatür taramasından yararlanılmıştır. Ele alınan geleneksel konutla ilgili literatür taraması yapılmış ancak yerel ölçekte kalan bu yapıyla ilgili herhangi bir yayına rastlanılmamıştır. Bunun yerine Karaağaç konut mimarisiyle ilgili yayınlar incelenmiştir. Bu yapının özellikleriyle Karaağaç konut mimarisinin genel özellikleri karşılaştırılmıştır. Bunların yanı sıra yerinde korunamamış, mevcut olmayan bu yapı için nasıl bir önerinin sunulması gerektiği ve kültür miraslarının bakımsızlık nedeniyle yıkılmaması için ne yapılması gerektiğine yönelik literatür taraması yapılmıştır.

$\mathrm{Bu}$ çalışmayla yıkılan bir kültür mirasının elde kalan verilerini literatüre kazandırmak hedeflenmiştir. Bu makalenin ikincil amacı da kültür miraslarımızın yıkılmasının önemli sebeplerinden biri olarak görülen bakımsızlık sorunuyla mücadele edebilmek için yeniden işlevlendirmenin önerilmesi ve özendirilmesidir.

Kadim şehir Edirne'nin önemli sayfiye yerlerinden biri olan Karaağaç; savaşlar, antlaşmalar, işgal direnişi, referandum, devletlerarası el değiştirme, mübadele gibi birçok siyasi, tarihî ve sosyolojik olaya tanıklık etmiş bir yerleşimdir. Mübadele öncesine kadar, Türkler ile Gayrimüslim ailelerin bir arada yaşadığı bu yerleşimde, geleneksel konut mimarisinin geniş bir yelpazesiyle karşılaşılmaktadır.

Bu makale kapsamında ele alınan konut, Karaağaç'taki diğer birçok geleneksel konut gibi iç sofalı plan tipinin karakteristik özelliklerini göstermektedir. Planda bir 
iç sofa ve dikdörtgen şekilli sofanın her iki uzun kenarında, ikişer odadan toplam dört oda bulunmaktadir.

Yerleşimdeki birçok konutta olduğu gibi yapı, sokakla ilişkilidir. Yapının, Dilaverbey Caddesi'nden doğrudan bir girişi bulunmaktadır. Yapıya taş bloklardan oluşturulmuş iki basamaklı merdiven ile girilmektedir. Bunun yanı sıra, köşe parselde yer alan konutun, İstiklâl Caddesi'nden de arka bahçeye girişi yer almaktadır.

Zemin kat, sofa ve dört odadan oluşmaktadır. Z1, Z2 ve Z4 odalarına sofadan; Z5 odasına, arka bahçeden ulaşılmaktadır. Z5 odasının kotu, arka bahçenin kotundadır. Geleneksel konut mimarisinde sıkça karşılaşılan pencere önü sediri, gömme dolap, gusülhane, ocak ve nişler bu konutta da kullanılmıştır. Z1 ve Z2 numaralı odaların pencere önlerinde sedir, sedirin tam karşısında Z1 odasında üç kanatlı bir gömme dolap, Z2 odasında ise dıştan iki kanatlı gömme dolap gibi görünen gusülhane yer almaktadır. Sedir, bu odalar için oturma işlevinde kullanılırken, bodrum kat için oluşturduğu yükselti sayesinde pencerelerin açılmasına olanak sağlamıştır. Zemin kattaki sofa, bir merdivenle sonlanmaktadır. Dört basamakla inilen ara sahanlıktan bahçeye çıkış sağlanmaktadır. Arka bahçede, muhdes bir tuvalet bulunmaktadır. Bahçe çıkışının olduğu ara sahanlıktan beş basamakla bodrum kata inilmektedir. Merdivenin hemen karşısında yer alan sofa altı (taşlık) mekânının, zemini taşlık olup tavanında döşeme kaplaması yoktur. Alttan örtülmeyen döşeme kirişlerinin yanı sıra mekânın ortasındaki ahşap dikmeler de görülmektedir. Sofa altı mekânının sağında, iki oda bulunmaktadır. Soldaki mekânlar, duvarla kapatıldığından belgelenememiştir.

Cephelerde, Karaağaç’taki geleneksel konut mimarisinin tipolojisine uyan, sade ve simetrik bir anlayışın hâkim olduğunu söylemek mümkündür. Bununla birlikte tipolojiye uygun olarak girişler cepheden içeri çekilmiştir. Kuzeybatı cephesinde, girişin sağında ve solunda yer alan pencerelerden hemen sonra başlayan $45^{\circ}$ açılı duvar, cepheye hareket katan bir öğe olarak kabul edilebilir. Yapının diğer yola bakan cephesinde, saçak altı silmesinin bezemesi dışında herhangi bir süsleme bulunmamaktadır. İç mekânı da oldukça sade olan konutun, sadece tavan çıtaları, tavan köşe silmeleri ve duvar silmeleri profillidir.

Özgün yapım sistemi, ahşap karkas arası kerpiç dolgu olup üzerine kıtıklı çamur sıva yapılmıştır. Bazı cephelerde, kıtıklı çamur sıva üzerine kireç sıva uygulanmıştır. Sonradan müdahale edilen kuzeybatı cephesinin bir bölümünde tuğla kullanılmıştır. Beşik çatının ve bahçe duvarının üzeri alaturka kiremitle kaplanmıştır.

2019 yılında yerinde yapılan incelemeye göre, yapının temel kalıntıları, birkaç ahşap dikmesi ve dolgu malzemesi dışında yapıya ait hiçbir öğe kalmamıştır. Dilaverbey Caddesi'nden bitişik komşusu olan yapının duvarında, yıkılan geleneksel konutun duvar ve çatı izleri bulunmaktadır. 
Yıkılmadan önce bu kültür mirasının belgeleme çalışmaları tamamlandığından rekonstrüksiyon önerisi akla gelebilir. Ancak bu kültür mirası, savaş veya doğal afet gibi bir felaket sonucu yıkılmamıştır. Bu durumdaki bir kültür mirası için rekonstrüksiyonun uygun olup olmadığı koruma otoriteleri tarafından hâlâ tartışılmaktadır. Rekonstrüksiyon kararı alınsa bile, yeniden üretilecek yapı, tarihî bir değer taşımayacaktır. Geleneksel konutların terk edilmesinin ve yıkılmasının sebepleri araştırılmalıdır. Bundan sonra, diğer kültür miraslarımızın yok olmasını önlemeye yönelik çalışmalar yapılmalıdır.

Büyük ailelerin küçük aileye dönüşmesi, gelir durumuna göre konut tercihinin değişmesi, çok amaçlı mekânlar yerine özelleşen mekânlara ihtiyaç duyulması ve yeni mekân gereksinimi, çağdaş yaşam araçlarına yönelme, kırsal yerleşimlerden kentsel yerleşimlere göç vb. modernite süreciyle karşımıza çıkan ve geleneksel konutların terk edilmesine sebep olmaktadır. Bunların yanı sıra yaşlılığa bağlı konut beklentisinin değişmesi, mirasçıların uzlaşamaması ve intikal işlemlerinin uzaması gibi sebepler de geleneksel yapıların işlevsiz kalmasına yol açmaktadır. Atıl kalan birçok kültür mirasının, bakım ve onarım çalışmalarında sürekliliğin sağlanamaması, bu yapıların yıkılmasına sebep olmuştur. Maalesef işlevsiz kalan yapıların yok olmaya mahkûm olduğu söylenebilir.

Kültür mirasının yok olması, toplum için geri dönüşü olmayan bir kayıptır. Toplumsal kimliğin oluşumunda rol oynayan bu yapıların yıkılmasını önlemek gerekmektedir. $\mathrm{Bu}$ amaçla öncelikle kültür mirasının taşıdığı değerler tespit edilmelidir. Sonrasında belgelenmesi, kayıt altına alınması, tescillenmesi, sürdürülebilir bir koruma politikasının geliştirilmesi gerekmektedir. Kültür mirasının gelecek kuşaklara aktarılması, sürdürülebilir koruma politikalarının oluşturulması ve bu politikaların toplum tarafindan benimsenmesi yoluyla sağlanabilir. Sürdürülebilir koruma yöntemi olarak bu yapıların yaşatılarak korunması önerilebilir. Bunun için günümüz konfor koşullarını sağlayacak düzenlemelerin yapılması gerekmektedir. Ancak yeniden işlevlendirme ya da işlevsel güncelleme adı altında yapının sömürülmesi de doğru değildir. Bu noktada dikkat edilmesi gereken husus, koruma - kullanım dengesidir. Bu dengenin kurulabilmesi için inşaat, makine ve elektrik mühendisi, sanat tarihçi ve koruma-restorasyon konusunda uzmanlaşmış mimarla birlikte disiplinler arası bir çalışma yürütülmelidir. Ortak yürütülecek çözüm önerilerinde hem kullanıcı istekleri hem de yapının özgünlük değerinin korunması göz önünde bulundurulmalıdır. 


\section{Introduction}

There are numerous examples of civil architecture in the Karaagac settlement of Edirne, which contain traces of the political, historical and sociological influences of the region and the basic characteristics of traditional residential architecture. One of these examples which is located on block number 866, parcel number 10-11 was documented in 2009. However, in the examination conducted in 2019, it was found that this building was not in place. The aim of the study is to record the architectural features of this traditional house in the light of the remaining data and to bring it into literature.

Researches related to residential architecture of Karaagac were carried out to interpret data of the building. Erdogan examined a few houses in Karaagac and generalized after giving information about the numbers of storey, construction technique and material, plan types. ${ }^{1}$ Emekligil Erdoğu stated that Karaagac's traditional residential architecture is different from Turkish traditional residential architecture as a result of her examination. She mentions that it has a different identity which is a combination of Rumelian and Balkanic minorities' housing culture and Traditional Turkish House. ${ }^{2}$ Arabulan made historical environment analysis of Karaagac in the extent of his doctoral thesis and determined characteristic features of Karaagac's architecture. ${ }^{3}$ Meral examined houses in Karaagac in order to define architecture of Karaagac and determined general features related to local residential architecture. ${ }^{4}$ Misirli and et al. determined natural and cultural elements of Karaagac District and present suggestions for strengthening these elements that are effective in forming identity. ${ }^{5}$

What is more, the second aim of this article is to suggest and encourage adaptive reusing to struggle against dilapidation/neglect which is one of the fundamental reasons for building demolitions. Through adaptive reusing, suggestions can be presented for sustainable preservation. There is a great number of articles about this subject. A few of them can be summarized as in the following:

Dikmen mentions that many traditional houses have been demolished because of some reasons such as social changes, preservation policies and lack of awareness and he also mentions that they need to be regained with adaptive reuse method in

1 Nevnihal Erdoğan, “Edirne’nin Eski Dış Bölgesi Karaağaç’ta Osmanlı Döneminde Yaşayan Azınlıkların Konutlar1," Yapı Dergisi 230 (2001), 57-66.

2 Rabia Erdoğu Emekligil, Geçmişin İzinde Karaağaç (İstanbul: Edirne Valiliği Kültür Yayınları, 2013), 88101.

3 Selin Arabulan, "Kentsel Dönüşüm Kapsamında Kimliğin Yeniden Kazanımı: Edirne - Karaağaç Örneği” (PhD Thesis, Trakya University, 2015), 76.

4 Aslı Meral, "19. Yüzyıl Mimarlığında Karaağaç İstasyon Kompleksi” (M.A. Thesis, Trakya University, 2016), 38-41.

5 Nilay Mısırlı, Tuğba Kiper and Aslı Korkut, "Doğal ve Kültürel Kent Kimliklerinin Belirlenmesi: Edirne İli Karaağaç Mahallesi Örneği," Journal of Bartın Faculty of Forestry 21 (1) (2019), 52-65. 
order for these to be transferred to future generations. ${ }^{6}$ Kuyrukçu et al. and İslamoğlu support that continuing the original function or adaptive reusing is effective in the sustainable preservation of cultural heritage. ${ }^{7}$ According to Grcheva industrial/ martial architecture can be preserved with adaptive reusing. Thereby cultural, social, economic, environmental benefits will be gained in addition to the protection of a cities memory. ${ }^{8}$ Mehr and Wilkinson, Bottero et. al., Vardopoulos, Plevoets and Sowińska-Heim, Pongsermpol and Upala, Hanafi et. al. and Sugden, state that adaptive reusing provides sustainable maintenance and repair of cultural heritage and so this will be effective in preserving them. ${ }^{9}$

\section{Material and Method}

The building survey, building survey report and photographs of the traditional house which is the subject of this study constitute the materials of the study. In this article, literature review is used as method. Literature review is made related to the traditional house but there are not any articles about this house at a local scale. Instead of this, articles that were published about residential architecture of Karaagac were examined. The plan, facade and ornament features of this house and general characteristics of Karaagac's architecture are compared.

Furthermore, literature review was made about what kind of suggestion should be presented for this unpreserved and non-existing house and also what needs to be done in order for cultural heritage not to be demolished because of neglect.

6 Çiğdem Belgin Dikmen, "Sustainability of Traditional Houses: Two Mansions Protected Through Adaptive Reuse in Yozgat," Gazi University Journal of Science Part B: Art, Humanities, Design And Planning 2(1) (2013), 69.

7 Emine Yıldız Kuyrukçu, Zafer Kuyrukçu and Dicle Aydın, "Geleneksel Konya Evlerinden Fuat Anadolu Evi’nin Yeniden Kullanım Bağlamında Değerlendirilmesi," Artium 3 (1) (2015) 79; Özge İslamoğlu, “Tarihi Yapıların Yeniden Kullanılmasında Yapı-İșlev Uyumu: Rize Müzesi Örneği," Journal of History Culture and Art Research 7(5) (2018), 511.

8 Olgica Grcheva, “Cultural Benefits of Former Military Buildings' Reuse: Public Room, Skopje, Republic of North Macedonia," TOLEHO 1(2) (2019), 76.

9 Shabnam Yazdani Mehr and Sara Wilkinson, "The Importance of Place and Authenticity in Adaptive Reuse of Heritage Buildings," International Journal of Building, Pathology and Adaptation 38(5) (2020), 689-690; Marta Bottero, Chiara D'Alpaos and Alessandra Oppio, "Ranking of Adaptive Reuse Strategies for Abandoned Industrial Heritage in Vulnerable Contexts: A Multiple Criteria Decision Aiding Approach," Sustainability 11 (2019), 1; Ioannis Vardopoulos, "Critical Sustainable Development Factors in the Adaptive Reuse of Urban Industrial Buildings: A Fuzzy DEMATEL Approach,” Sustainable Cities and Society 50 (2019), 2; Bie Plevoets and Julia Sowińska-Heim, "Community Initiatives as a Catalyst for Regeneration of Heritage Sites: Vernacular Transformation and Its Influence on the Formal Adaptive Reuse Practice," Cities 78 (2018), 128-129; Chotewit Pongsermpol and Prapatpong Upala, "Impacts of Adaptive Reuse of Heritage Buildings Converted to Small Hotels in Bangkok," Asian Journal of Quality of Life (AjQoL), 3(13) (2018), 69; Mohd Hanizun Hanafi, et al. "Essential Entities Towards Developing an Adaptive Reuse Model for Organization Management in Conservation of Heritage Buildings in Malaysia," E-BPJ 3(7) (2018), 265; Evan Sugden, "The Adaptive Reuse of Industrial Heritage Buildings: A Multiple-Case Studies Approach" (M.A. Thesis, University of Waterloo, 2018), 11-110. 


\section{Brief History of the Settlement}

Edirne, whose history dates back to prehistoric times, is regarded to be in the Ottoman territories in $1361^{10}$. Numerous examples of public and civil architecture were built in Edirne, which became richer thanks to the importance given by the Ottoman sultans to the construction works along with the traces of the Roman period. However, there are also important architectural examples from the Republic Period ${ }^{11}$.

Karaagac, a settlement in Edirne, has many cultural properties that need to be preserved, just as it is in Edirne city centre. The settlement within the urban site area has largely preserved the hippodamic urban plan despite the deterioration in the northwest and southeast.

Despite plenty of cultural and historical traces, there is insufficient information about the history of the settlement. Although it is stated that it was founded on the ancient city of Orestia, there is no archaeological data supporting this information yet ${ }^{12}$. In Byzatine Period, it is known that there was another small settlement in the place of Karaagac. After the conquest of Edirne, the importance of this settlement increased ${ }^{13}$. Especially in $17^{\text {th }}$ century, Edirne was known to expand to K1y1k and Karaagac ${ }^{14}$.

In the seventeenth century, Karaagac was referred as a settlement with a predominantly Greek population and whose livelihood was mostly winemaking ${ }^{15}$. In the nineteenth century, when the right to open a consulate in order to facilitate the commercial activities of foreign merchants was granted ${ }^{16}$, many consuls settled in Karaagac. In addition, it is known that there are Armenian and Italian families in the settlement and that there is a small number of Turkish summer houses ${ }^{17}$.

Considered as a settlement inhabited by wealthy Turkish families and non-Muslims, the architectural texture of Karaagac consists mostly of examples of civil ar-

10 Şevket Aziz Kansu, Edirne'nin Tarihöncesine Ait Araştırmalar: Edirne’nin 600. Fethi Yıl Dönümü Armăgan Kitabl, (Ankara: Türk Tarih Kurumu Basımevi, 1993), 13-20; Halil İnalcık, Edirne 'nin Fethi (1361): 600. Fethi Yıl Dönümü Armağan Kitabı (Ankara: Türk Tarih Kurumu Basımevi, 1993), 137-160.

11 Nevnihal Erdoğan, "Edirne'de Mimarlığa Bakış," Türkiye’de Mimarlık, Yıldız Buluşmaları 06 Toplantıları (İstanbul: Umut Matbaası/Çanakkale Seramik Kalebodur, 2007), 23-33.

12 Emekligil Erdoğu, Geçmişin İzinde Karaă̆aç, 13-14.

13 Besim Darkot, “Edirne, Coğrafi Giriş,” Edirne’nin 600. Fethi Yıl Dönümü Armağan Kitabı (Ankara: Türk Tarih Kurumu Basımevi, 1993), 1-12.

14 Hakan Yaş and Can Çetin, "Edirne’nin Kentsel Genişlemesinin İmar Planları üzerinden İncelenmesi," Kentleşme ve Yerelleşme Sürecinde Edirne Monografisi. Ed. Mahmut Güler and Seyhan Güler (İstanbul: Marmara Belediyeler Birliği Kültür Yayınları, 2019), 125-126.

15 Emekligil Erdoğu, Geçmişin İzinde Karaağaç, 16.

16 Mübahat Kütükoğlu, "Osmanlı İktisad Tarihi Bakımından Konsol Raporlarının Ehemmiyeti ve Kıymeti”, Güney Doğu Avrupa Araştırmaları Dergisi, 10 (99) (1983), 151.

17 Emekligil Erdoğu, Geçmişin İzinde Karaağaç, 16-17; Erdoğan, “Edirne’nin Eski Dış Bölgesi Karaağaç’ta Osmanlı Döneminde Yaşayan Azınlıkların Konutları”, Yapı Dergisi, 57-66. 
chitecture ${ }^{18}$. With the arrival of the railway in $1872^{19}$, the railway station and other service buildings which are among the architectural monuments of Karaagac today were built. Apart from these, Karl Baedecker reports that there are buildings providing accommodation, restaurants and education ${ }^{20}$. During this period, the cold storages where the famous cheese of Edirne was stored and the cocoon ovens used in cocoon production were also located in Karaagac ${ }^{21}$. In addition to these, there were also mills and factories in relation to production ${ }^{22}$.

After several changes of ruling, Karaagac was left to Greece by a referendum in 1920 which was affected by historical and political events such as, the Balkan War, First World War, The Treaty of Sofia and the establishment of the Inter-Allied Thracian government. Later, a resistance against the Greek occupation, which was historically referred as the Battle of Karaagac, was started ${ }^{23}$. On July 24th, 1923, Karaagac was taken as compensation from the Greek government by the Treaty of Lausanne, and today it is a district of Edirne ${ }^{24}$. Greeks living in Karaagac were sent to Greece in accordance with the provisions of the exchange, and Turkish families living in Western Thrace were placed here ${ }^{25}$.

\section{Documentation Studies of 2009}

\section{Location of the building}

Located on the border with Greece and Turkey, Karaagac is in $3.5 \mathrm{~km}$ northwest of the town of Kastanies, Greece, and $4.5 \mathrm{~km}$ southwest of Edirne. Transportation from Edirne to Karaagac is provided via Lausanne Street, which firstly passes over the Tunca and Meric rivers and then passes through the urban forest and farmland. This street which provides access to the settlement is also an important axis (F. 1). At the end of the street, Edirne Station Building, which is one of the most important landmarks of Karaagac, and its service buildings are reached. There is Lausanne Monument near the station building which was built in the northwest direction.

18 Darkot, "Edirne, Coğrafi Giriş," 1-12; Nevnihal Erdoğan, Edirne Kentinde Konut Yerleşimlerinin Fiziksel ve Sosyal Yapısınin Kültür Bağlamında Değerlendirilmesi (Edirne: Trakya Üniversitesi Rektörlüğ̈̈ Yayını, 2006), 44.

19 Darkot, "Edirne, Coğrafi Giriş," 1-12.

20 Karl Baedecker, Konstantinopel Balkanstaaten, Kleirasien, Archipel, Cypern (Leipzig: Verlag Von Karl,1914), 50-55; Emekligil Erdoğu, Geçmişin İzinde Karaağaç, 18.

21 Mustafa Budak, "Paris Barış Konferansı Sürecinde (22 Mart-10 Nisan 1922) İtilâf Devletlerine Sunulan Batı Trakya Hakkında İki Muhtıra", Türkiyat Mecmuası 27(2) (2017), 114.

22 Erdoğan, Edirne Kentinde Konut Yerleşimlerinin Fiziksel ve Sosyal Yapısının Kültür Bă̆lamında Değerlendirilmesi, 44.

23 Emekligil Erdoğu, Geçmişin İzinde Karaağaç, 18-20.

24 Sedef Bulut, "Balkan Savaşları'ndan Lozan'a Batı Trakya Meselesi ve Mustafa Kemal Atatürk'ün Batı Trakya Politikası," Gazi Türkiyat Dergisi 1 (3) (2008), 94; Budak, "Paris Barış Konferansı Sürecinde (22 Mart-10 Nisan 1922) İtilâf Devletlerine Sunulan Batı Trakya Hakkında İki Muhtıra," 103.

25 Türk Tarih Kurumu, Düstur 3.Terpip - Lozan Sulh Muahedenamesinin Kabulüne Dair Kanunlar (İstanbul: Necmi İstikbal Matbaası, 1931), 5: 260-270. 


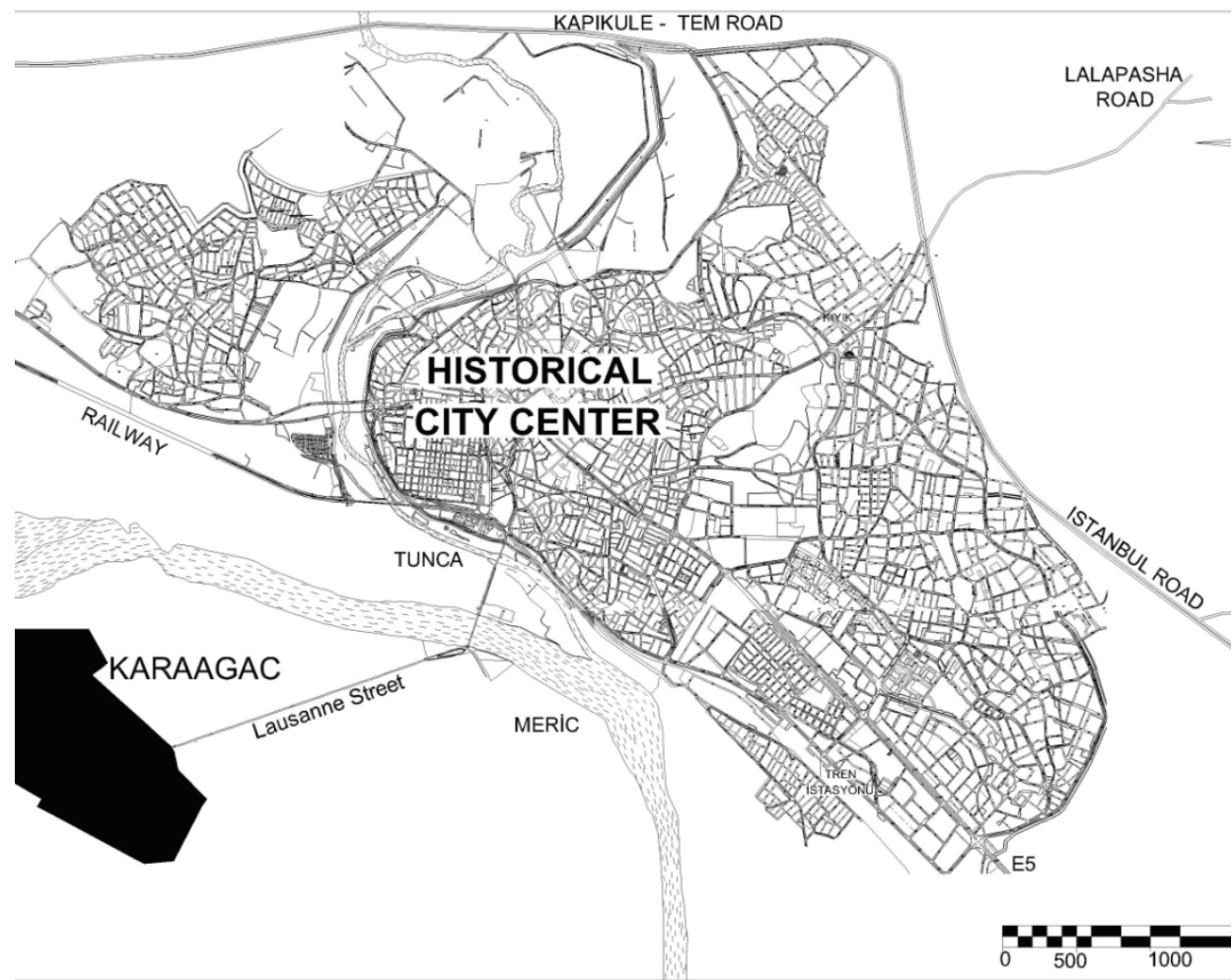

F. 1: Location of Karaagac According to Edirne City Centre (EMA $\left.{ }^{26}, 2011\right)$.

The house that was examined in the extent of the study is located in Edirne Province, Karaagac District, 39 sheet, 866 block, 10-11 parcel, 35 door number. The southwest and northwest parcels of the registered parcel located at the intersection of Istiklal Street and Dilaverbey Street are empty. There is Yeni Cami (New Mosque) in Karaagac District in west and there are adjacent buildings in southeast (F. 2).

26 The abbreviations used in this article are as follows: EMA: Republic of Turkey Edirne Municipality; CCCP: Council for the Conservation of Cultural Property; TTK: Turk Tarih Kurumu (Turkish Historical Society); PA: Personal archive of the author; WHC: World Heritage Committee; ICOMOS: International Council on Monuments and Sites 


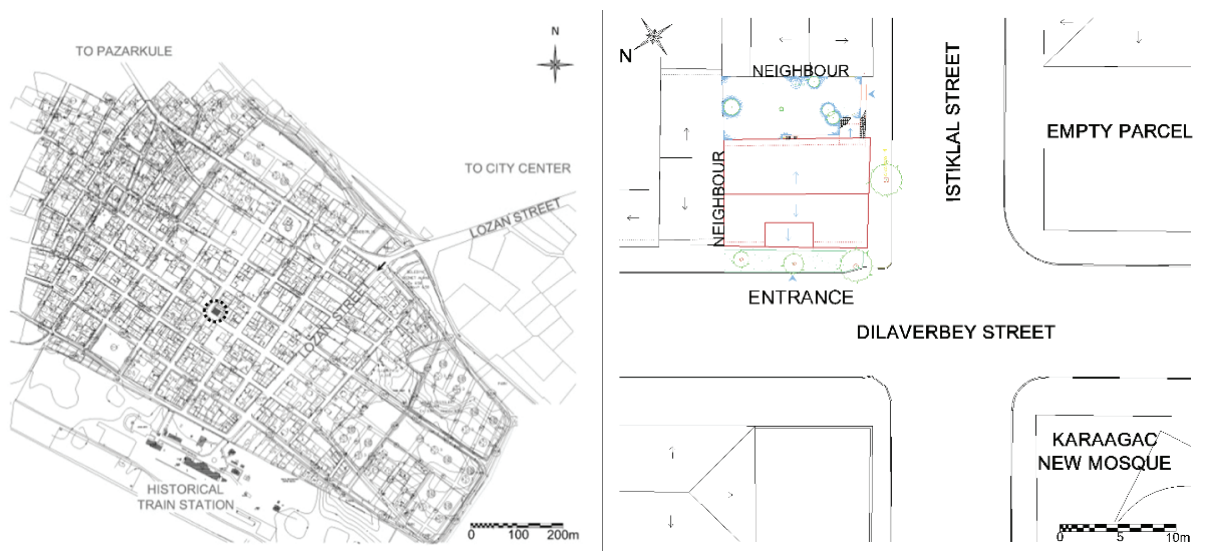

F. 2: Location of the House in Karaagac (EMA, 2011).

\section{Features of plan}

General characteristics of traditional houses in Karaagac $\operatorname{are}^{27}$ :

- Generally being in a garden,

- A garden sometimes on street, sometimes behind and/or adjacent,

- A symmetrical facade, an entrance in middle (rarely on the right or left)

- An entrance that is back from the front facade line

- An entrance that is directly on the street (entry from the garden if any garden exists)

- Entries from both roads on the corner parcels

- Double door for entrance

- The construction system is generally timber frame with adobe infill (there are also examples of stone or brick)

- Having one and a half storey or two storeys (few have three storeys)

- Generally basement floor + ground floor, basement floor + ground floor + attic or ground floor + extension

- Ground floor is used for rooms, basement floor is used for woodshed and kitchen.

27 Emekligil Erdoğu, Geçmişin İzinde Karaağaç ,88-101; Arabulan, "Kentsel Dönüşüm Kapsamında Kimliğin Yeniden Kazanımı: Edirne - Karaağaç Örneği,”76; Meral, “19. Yüzyıl Mimarlığında Karaağaç İstasyon Kompleksi,” 38-41; Erdoğan, "Edirne'nin Eski Dış Bölgesi Karaağaç’ta Osmanlı Döneminde Yaşayan Azınlıkların Konutları," 57-66. In this title, Karaaağaç residential architecture is mentioned. You can review the following publications for Edirne residential architecture: Sennur Akansel, "Edirne Kaleiçi Geleneksel Konutlarında Plan ve Cephe Analizleri”, (M.A Thesis, Trakya University, 1990); Sennur Akansel, "Edirne Kaleiçi Geleneksel Konutlarının Plan ve Cephe Özellikleri.” S.Ü. Mühendislik Mimarlık Fakültesi Dergisi 19 (1) (2004): 101-112; Sennur Akansel, "Edirne Kaleiçi Geleneksel Konutları ve Kaleiçi'nin Günümüzdeki Görünümü.” Trakya Univ J Sci 5(2) (2004): 199-207; Damla Zeybekoğlu, "Edirne Geleneksel Konut Mimarlığını Etkileyen Sosyo-Kültürel Faktörlerin İncelenmesi”, (M.A. Thesis, Trakya University, 2005); Goncagül Meriç, “Edirne Kaleiçi Evleri 1903 Sonrası”, (M.A. Thesis, Bursa Uludağ University, 2019). 
- The house plans are generally rectangular or square-like (rarely L type)

- Houses are generally with inner sofa type or different versions of this plan type (F. 3) ${ }^{28}$,

- Having not too wide eaves

Although residential architecture of Karaagac has similar features with Traditional Turkish House (such as plan schemes, construction technique), it differentiates in some features such as entries opening to the street, a great number of window, not hiding window front with cages etc. ${ }^{29}$ Furthermore, residential architecture of Muslim and Non-Muslim have similar characteristics thanks to cultural interaction in Karaagac ${ }^{30}$.

When the plan features of this traditional house that is the subject of this article are examined, inner sofa (karniyarık) plan which is common in the settlement is seen. In this inner sofa plan type that is named after the position of sofa according to rooms, sofa is inside ${ }^{31}$. There are four rooms in total, two of which are on both long sides of rectangular-shape sofa. In accordance with settlement generally, basement floor was used as kitchen, woodshed or room and ground floors were used as rooms. The entrance of the house is back from the front facade line and directly on the street.

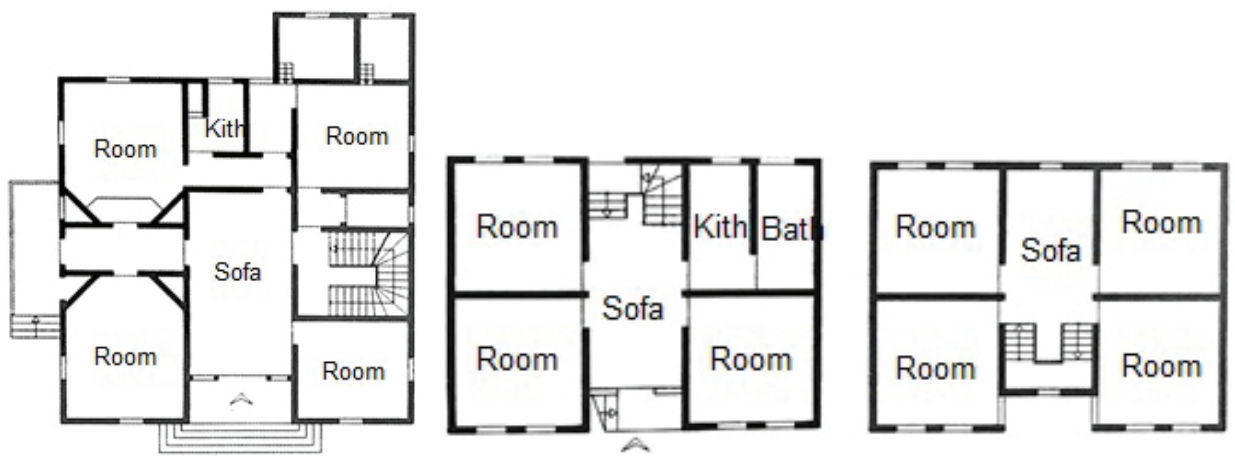

a) Saadet Charity House Plan b)Sakir Kayalar House Plan c) Senol Atesci House Plan

F. 3: Plan Examples from Traditional House Architecture in Karaagac (Erdogan, "Edirne'nin Eski Dış Bölgesi Karaağaç’ta Osmanlı Döneminde Yaşayan Azınlıkların Konutları,” 59-65).

28 Erdoğan, “Edirne'nin Eski Dış Bölgesi Karaağaç’ta Osmanlı Döneminde Yaşayan Azınlıkların Konutları,” 59-66.

29 Emekligil Erdoğu, Geçmişin İzinde Karaağaç, 91-92.

30 Arabulan, "Kentsel Dönüşüm Kapsamında Kimliğin Yeniden Kazanımı: Edirne - Karaağaç Örneği," 76.

31 Sedat Hakkı Eldem, Türk Evi Plan Tipleri (İstanbul: İTÜ Mimarlık Fakültesi Yayını, 1968), 92. 


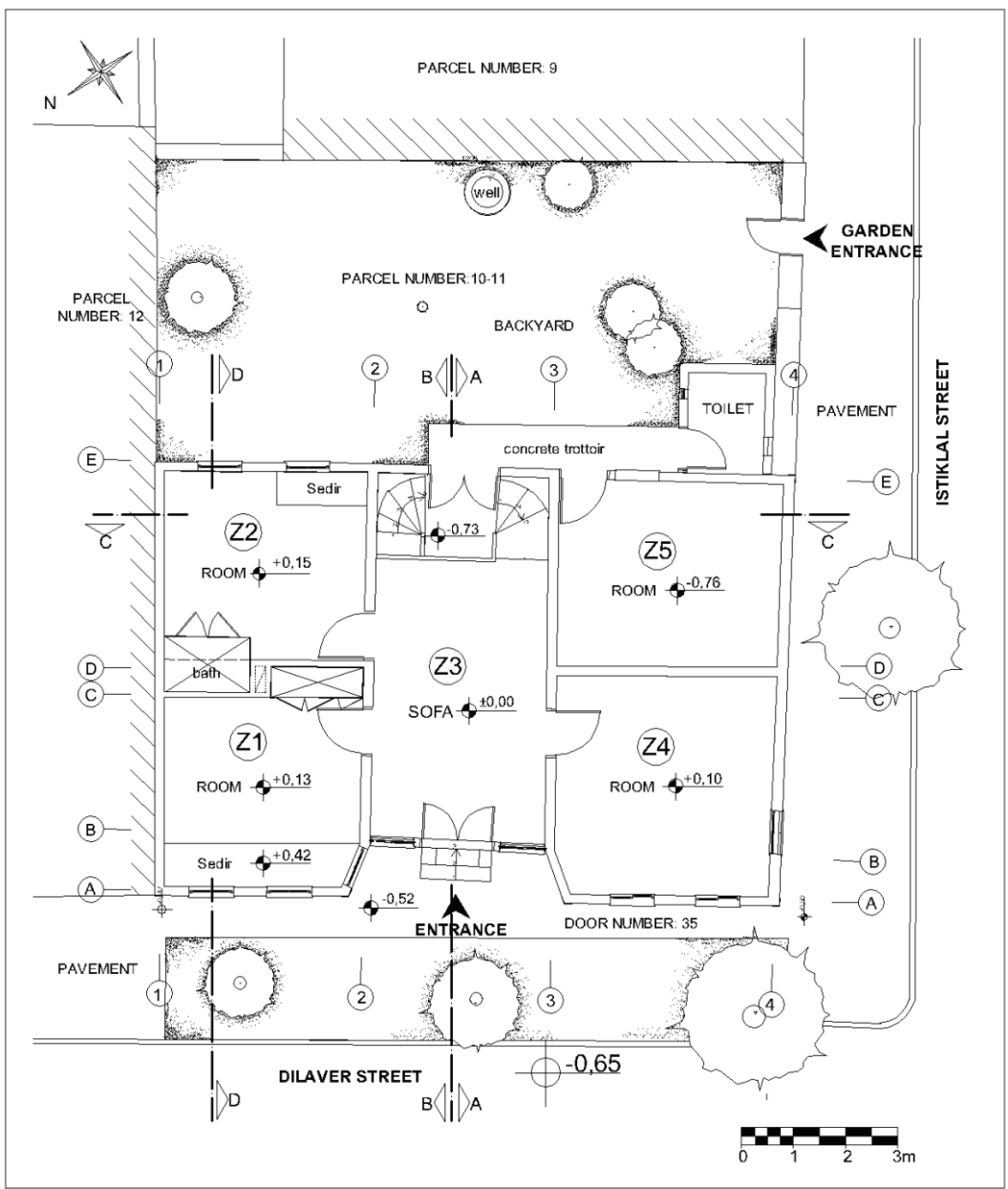

F. 4: Ground Floor Plan of the House (PA/22.12.2009)

\section{Ground floor plan}

There is an entrance gate on Dilaverbey Street which provides direct entry to the House. The building is entered from a 2-step staircase made of stone blocks. There is also an entrance to the backyard from Istiklal Street (F. 4).

The ground floor consists of a sofa, four rooms and a restroom located in the backyard. The ground floor rooms have timber floors, ceilings, doors, windows, sills, casings and mouldings. The sofa ends with a staircase. There is an exit to the garden from the landing. Inside the garden, a concrete trottoir (pavement) is seen turning to the right. It was used to reach the $\mathrm{Z} 5$ room and the restroom which was built afterwards. In addition, there are four plum trees, grapevine and a water well that was thought to be original (F. 4). 
Sofa (Z3): The first space we meet after opening the entrance door is the sofa. The Sofa has a unifying position for all rooms and provides distribution to Z1, Z2 and Z4. The sofa has two original sash windows facing the entrance, an entrance door, three doors to the rooms and one door to the garden. The level of the sofa is $10-15 \mathrm{~cm}$ lower than the level of the rooms. All doors opening from the rooms on the ground floor to the sofas are original panelled doors and have unoriginal oil paint on them. On the sides of the doors facing the sofa side, they are covered with green stiles and rails and brown panels. When the door handles are examined, it is understood that they are original.

The width of the timber covering in the floors is smaller than in other rooms and this data indicates that it may have been changed later than the others. A large part of the roof of the sofa has collapsed. The collapsed roof pieces are piled on the floor $(\mathrm{F}$. $5)$. The sofa and rooms have a profiled wall moulding which passes approximately in the middle of the floor height. Where the wall and ceiling meet, there is a profiled ceiling moulding, and where the wall ends with the floor, there is a baseboard (F. 5, F. 6). They are painted green and the place is painted blue. The railing of the staircase on the sofa is made of metal and is not original. The timber railings on the steps and the landing are original (F. 7, F. 9). Stair coverings are also made of timber.

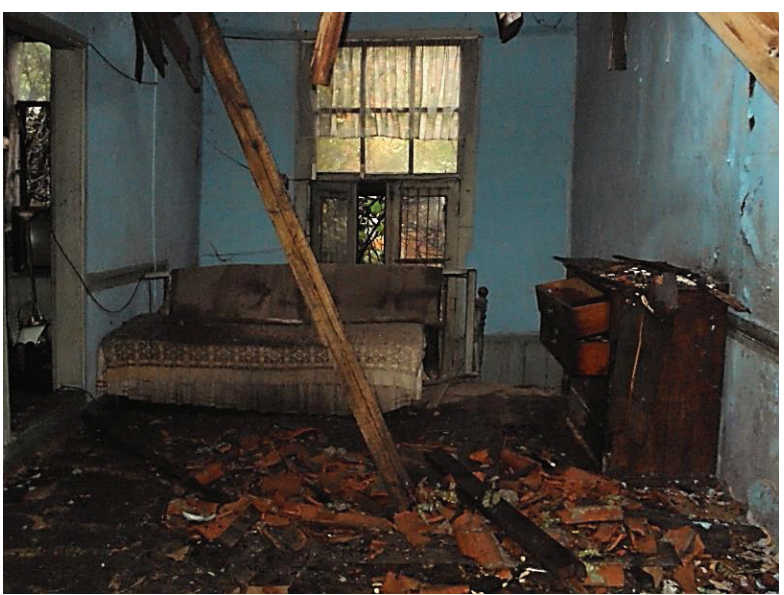

Sofa (PA/23.10.2009)

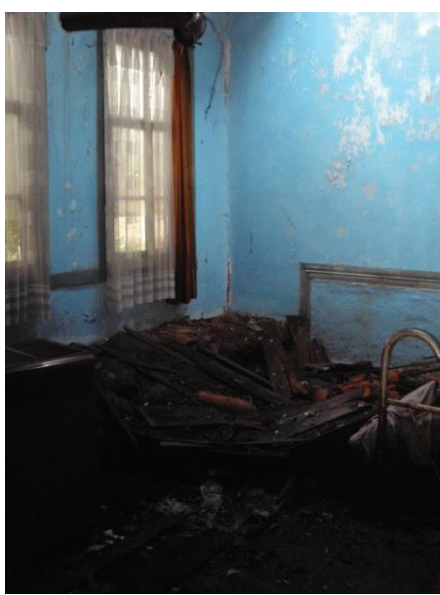

Z1 Room (PA/23.10.2009)

F. 5: Photo from Sofa and Z1 Room 


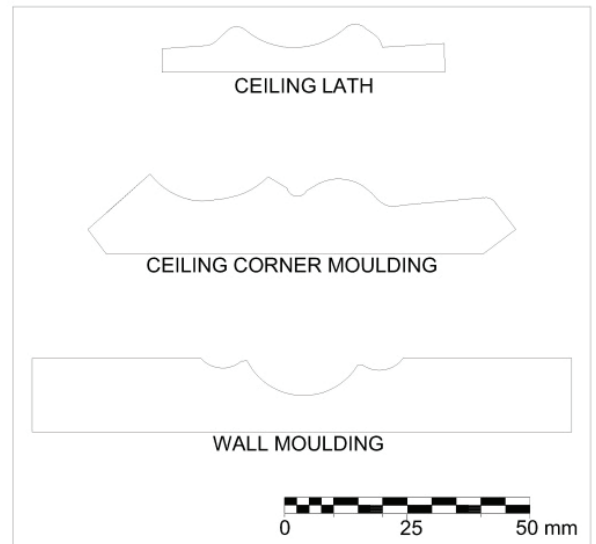

F. 6: Profile Details(PA/22.12.2009)

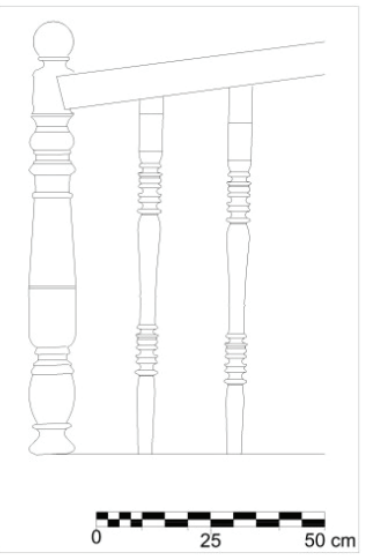

F. 7: Timber Staircase Detail (PA/22.12.2009)

$\mathrm{Z} 1$ room: The room is high as $13 \mathrm{~cm}$ from the sofa. There is a built-in wardrobe and a sedir (a kind of fixed couch) in front of the window on the left. Sedir while served as the seating function for this room has enabled the window to be opened thanks to the elevation it created for the basement floor (F. 5, F. 8). The windows of this room are not original. The surface of all windows and doors in rooms on the room side is dark brown oil paint. Unlike other rooms, the ceiling covering has rounded corners and a simple pattern. Dark brown oil paint was used on the ceiling. Part of the roof and ceiling collapsed. There is blue paint on the walls. The mouldings on the wall, baseboards, built-in wardrobe and door are painted green.

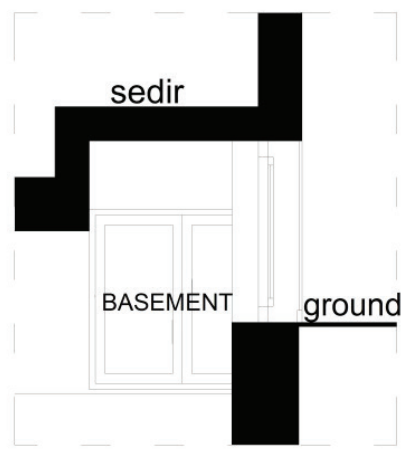

F. 8: Location of Sedir and Window (PA/22.12.2009)

$\mathrm{Z} 2$ room: The room is $15 \mathrm{~cm}$ above the sofa level. On the left side, there is a built-in brown painted bathing cubicle (gusülhane). The inside of the bathing cubicle which looks like a wooden built-in wardrobe from the outside was used as a wall surface with oil paint. On the right, there is a sedir as in the $\mathrm{Z} 1$ room. Part of this sedir has been removed or demolished. This part is covered with non-original floor covering at the floor level of the room. The Z2 room have windows with two casements. The 
windows are painted dark brown. The walls are painted pink and the moulding and baseboards on the wall are painted dark brown.

Z4 room: The room is $10 \mathrm{~cm}$ above the sofa level. The room's windows facing the entrance are not original. A small latch was used instead of casement bolt in the window opposite the entrance of the room and overlooking Istiklal Street. Outside this window, there is a timber louvre. Unlike the Z1 room, there is no windows on the chamfered wall of the room. The walls are green. The mouldings on the walls were painted and covered.

$\mathrm{Z5}$ room: The entrance to this room is from the garden. Its level is $76 \mathrm{~cm}$ lower than the level of the sofa. This room has no ceiling, and the roof has collapsed. The storey height of the room is high because the floor is at a low level and there is no ceiling panelling. This room was used for storage purposes by the last resident. The room has a window opening and casings, but no window frame or casement is found.

Toilet: The toilet did not exist in the house originally. Only the window frame facing the backyard is left, while the window facing the path of the toilet has no frame or casement, only the window opening can be seen.

\section{Basement Plan}

When five steps are followed from the landing of the staircase, the basement floor is reached. On the basement floor, there is an under-sofa space (taşlik) directly opposite. The room on the right at the entrance to the basement floor was used as a kitchen. There is another room next to the kitchen. There are no entrances to the rooms on the left side of the under-sofa space (taşl1k). It was closed in the form of a wall with the traditional technique. Therefore, documentation of these spaces could not be carried out (F. 19).

B3 Under-sofa (stony) space: The wall belonging to the entrance facade is thicker than the wall on the upper floor and it was constructed in the form of a stone wall. The construction of a non-plastered timber frame with brick wall on the stone wall caused this wall to become thinner (F. 9).

On the wall on the side of the staircase, there is a niche and a window opened from the landing of the staircase. Just behind the entrance door, there is a window facing the kitchen.

The floor surface is stony and there is no coating on the ceiling, and the floor beams are observed. In the middle of this room there are two carrier timber posts which were thought to have been added later. The third one was placed on the wall (F. 9, F. 10). 


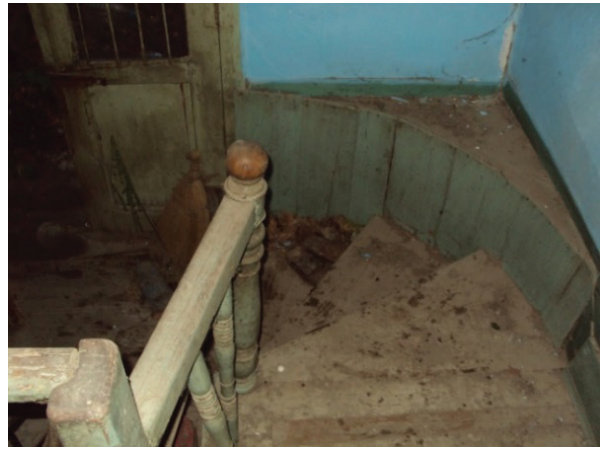

Staircase (PA/23.10.2009)

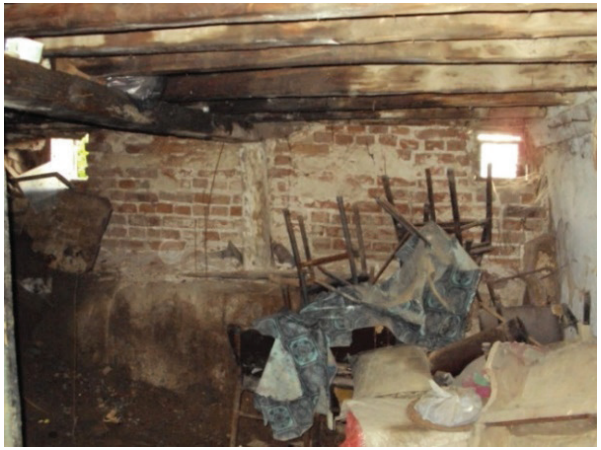

Under-Sofa Space (Taşlık) (PA/23.10.2009)

F. 9: Stairs Leading Down to the Basement and Under-Sofa Space (Taşlık) Photo

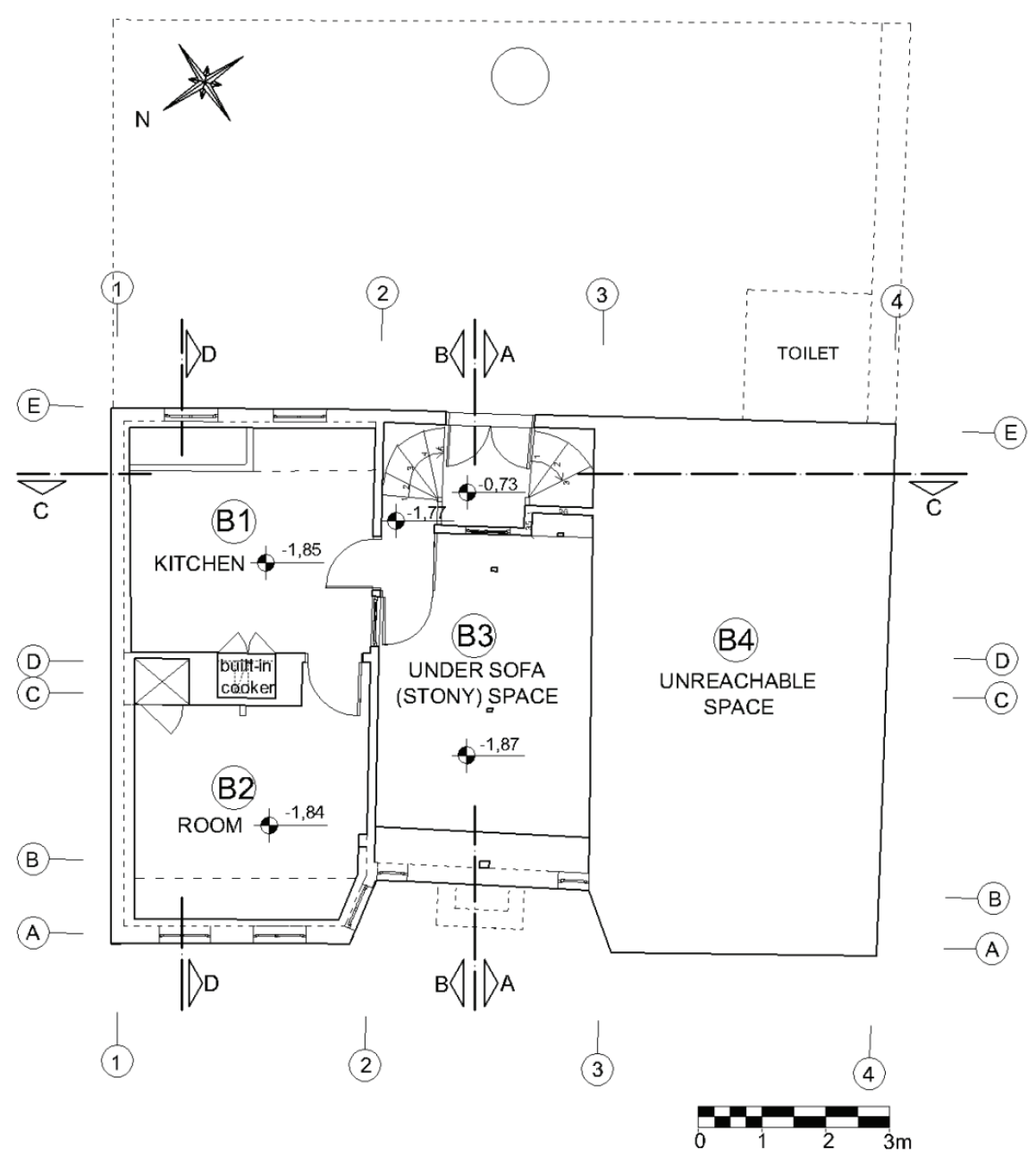

F. 10: Basement Plan of the House (PA/22.12.2009) 
B1 kitchen: There is a timber doorstep at the entrance. The first window on the right is opened using the height of the sedir. The other window does not open because the sedir is removed (F. 10, F. 11). When the windows are examined, it is seen that unlike other basement windows, a small latch is used instead of casement bolt. As the wall from the upper floor turned into a stone wall, the wall width increased. The kitchen has a cast concrete sink and a built-in fireplace with fire door; however, its surface has some deterioration. The flooring of the kitchen is cement screed and the ceiling is covered with timber.

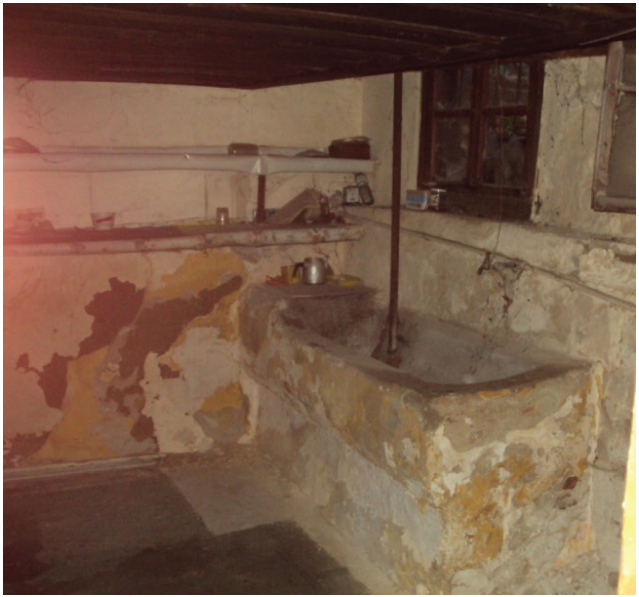

B1 Kitchen (PA/23.10.2009)

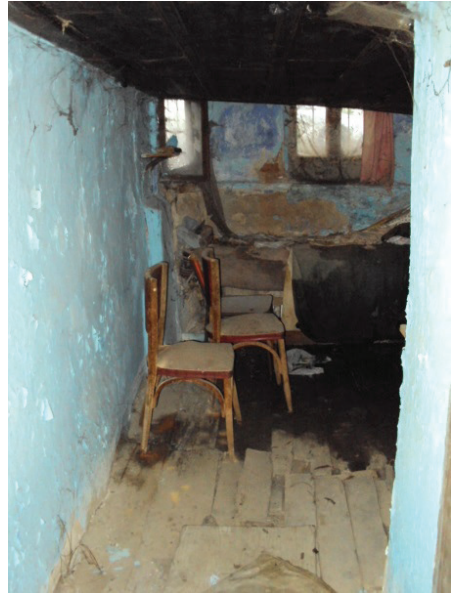

B2 Room (PA/23.10.2009)

F. 11: Photo from Kitchen and B2 Room

B2 room: The wall thickness increases because of the stone wall. Two windows are opened above this level. There are also windows on the chamfered wall. The room has a built-in closet (F. 10, F. 11). The flooring and ceiling covering are made of timber. The floor has deflection and some places of the floor collapsed.

\section{Facade properties}

It is possible to say that there is a simple understanding of the facade that fits the typology of traditional residential architecture in Karaagac. The Northwest facade, where the entrance of the building is located, is designed almost symmetrically. The $45^{\circ}$ angled wall, which begins immediately after the windows to the right and left of the entrance, can be considered as an element that adds movement to the facade. The other facade of the building in the corner parcel is quite plain and only under-eaves moulding of the façade is elaborated.

\section{Northwest facade}

The three large acacia trees in front of this facade weaken the perception of the building entrance; however, instead of removing this green tissue in the section re- 
served for the pavement, maintenance (pruning, irrigation, cleaning of leaves, etc.) is recommended to protect it.

At first glance, symmetry appears to prevail in the facade layout of the building, but when examined carefully, it is seen that it is not fully symmetrical. Facade height is $5.35 \mathrm{~m}$.

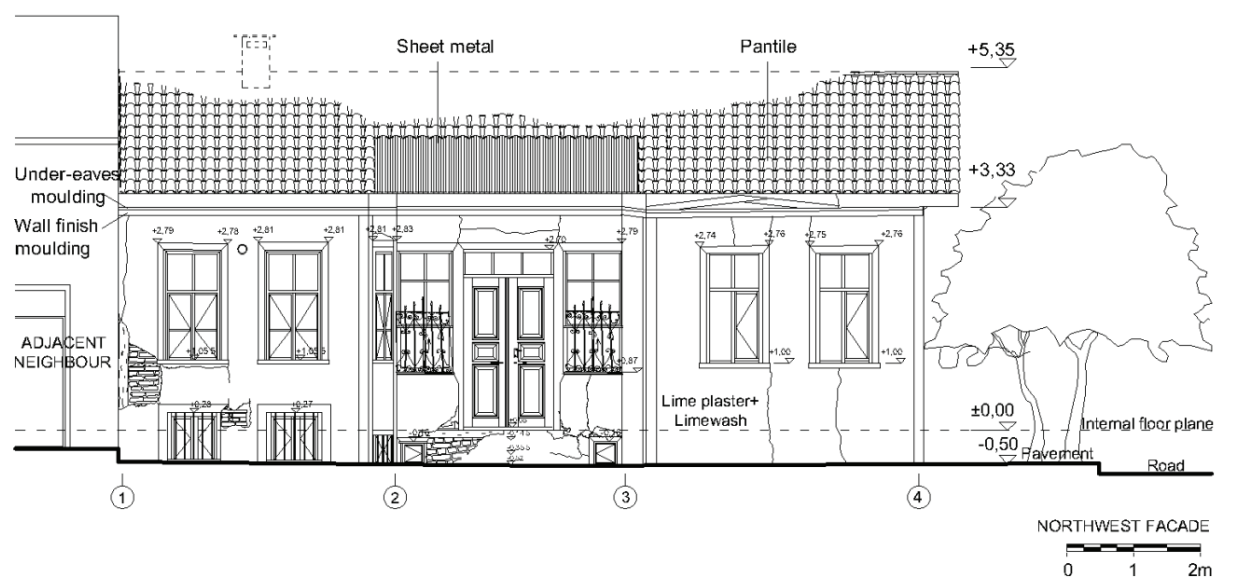

F. 12: Northwest Facade of the House (PA/22.12.2009)

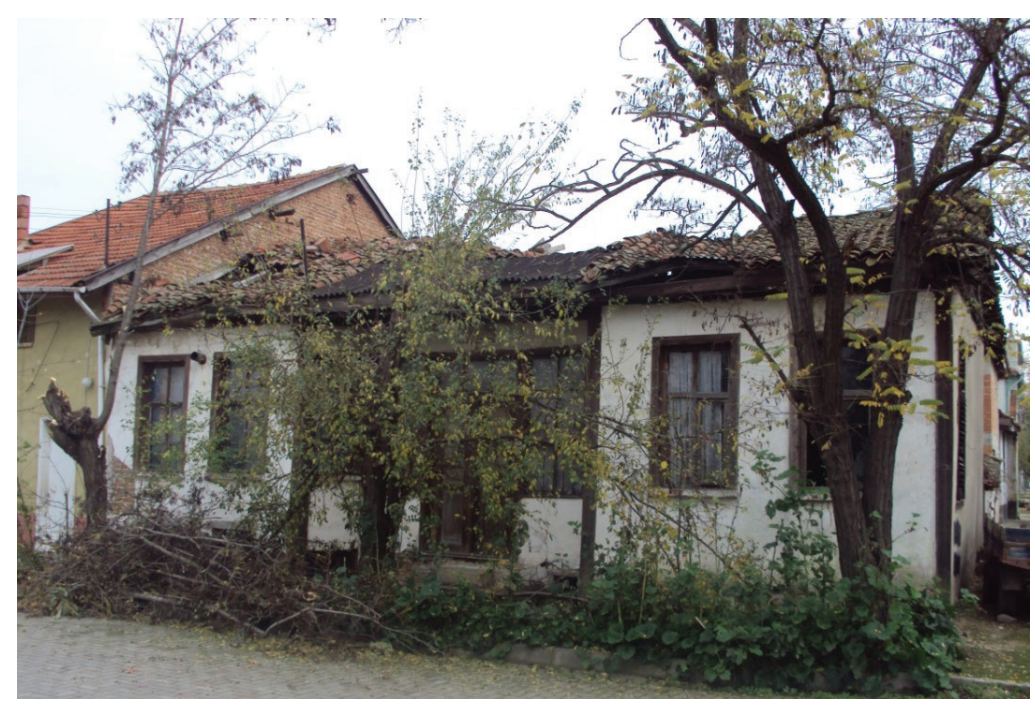

F. 13: Photograph Showing the Northwest Facade of the House (PA/18. 11. 2009)

The walls of this facade have been renovated with a timber frame with brick infill. The lime plaster and whitewash are used on the facade. The posts in the corners of the building are not plastered but they are covered with vertically timber claddings. Where the wall ends and the roof begins, there is a wall finish moulding and under-eaves 
moulding. It has a very plain facade without any ornamentation. The roof is mission tile and there is a corrugated metal sheet roof covering just above the entrance (F. 12, F. 13). There are no traditional gutters and pipes on the roof. Only eaves were used.

Only the sash windows on either side of the entrance door are original. Profile strips were preferred on the rail of the windows. The windowsill is timber. In front of these windows is curved wrought ironwork. The other windows on the ground floor have been modified and the windowsills are concrete. There is a timber casing around the windows on the ground floor. Other basement windows, except for the basement windows at the entrance, have concrete casing and iron bars in front of them (F. 12).

The door has a timber sill and it is an example of a panelled door. Panelled doors are used mostly in interior doors due to the fact that water flows from the panels and water enters from the stiles and rails. However, with the fashion coming from Europe in the last century, it is seen that the main doors are also made with panelled doors. As in this example, in many buildings such doors are located in entrances pulled in from the facade. There is a fixed glass section above the door. Timber casings are wrapped around the door, as are the windows. Both leaves of the door were arranged to be opened and the iron door handles were worn over time and some parts were broken (F. 12).

\section{Southeast facade}

The facade wall is the timber frame with brick infill. On the mud plaster the lime plaster was applied and also whitewash was applied on it. Also, timber under- eaves moulding exists on this facade (F. 14).

Both casements of the windows can be opened and closed. There are timber casings around the windows on the ground floor while the windowsills are made of concrete. The basement windows have concrete casings and have bars in front of them (F. 14).

The door that opens to the garden has six panels; the middle and the top are glass and it has iron bars inside. It is understood that the door was original when looking at the door. Above the door, there is a fixed glass section that lights up the sofa (F. 14).

The door next to this door provides access to the Z5 room which is used from the garden. A window space is located right next to this batten door with timber sill. There is no, frame in this space. The door of the toilet is also batten door and there is no frame in the window, only space is available. The toilet consists of a timber frame with brick filling, mud-plastered walls. The roof of the toilet is also made of mission tile (F. 14). 


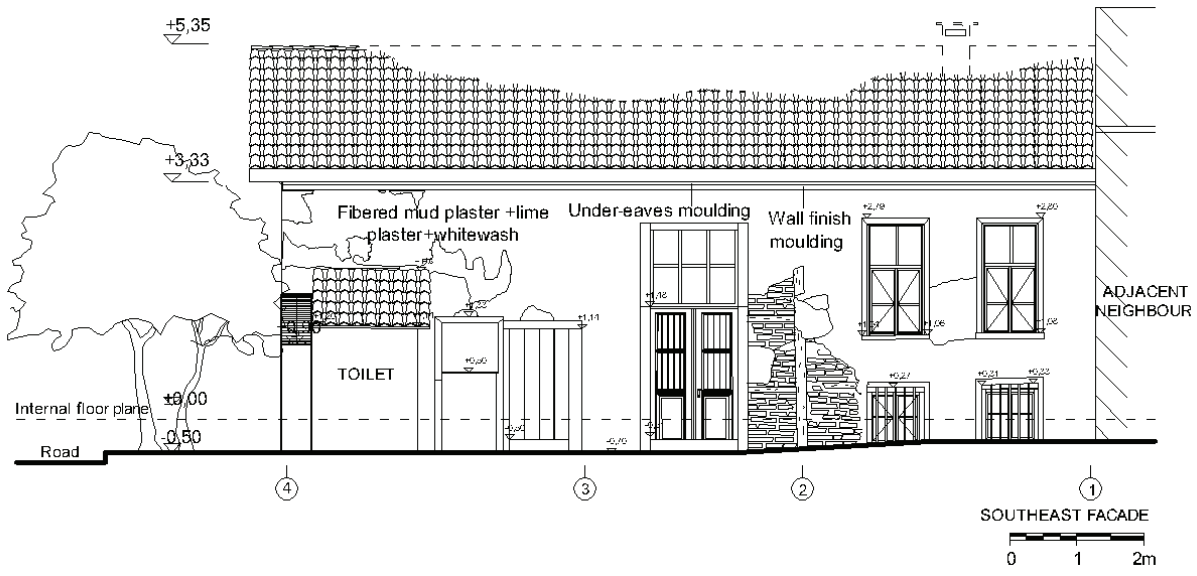

F. 14: Southeast Facade of the House (PA/22.12.2009)

\section{Southwest facade}

The facade wall underwent renovations, as did the northwest facade. White lime wash was applied on lime plaster. The corners of the building are completed with vertically timber claddings. The pediment of the gable roof is covered with vertically timber claddings. Beneath these claddings there are the ornamental under-eaves moulding; however, these decorations have largely fallen and broken (F. 15). Below the moulding there is a wall finish moulding as on the other facades.

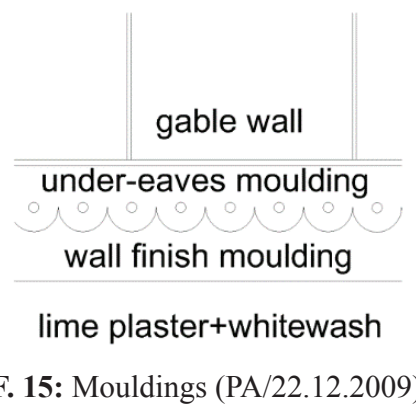

The garden wall was adobe masonry and on the mud plaster and whitewash was applied. As it was identified from the fallen parts of the plaster, bonding timber were sometimes placed on the adobe brick pile. On top of the wall, four rows of mission tiles were placed on a row of bricks. The garden door is a single-leaf, batten door. A single window can be seen on this facade. There is louvre outside this window. Timber casings are surrounded by this louvre (F. 16, F. 17). 


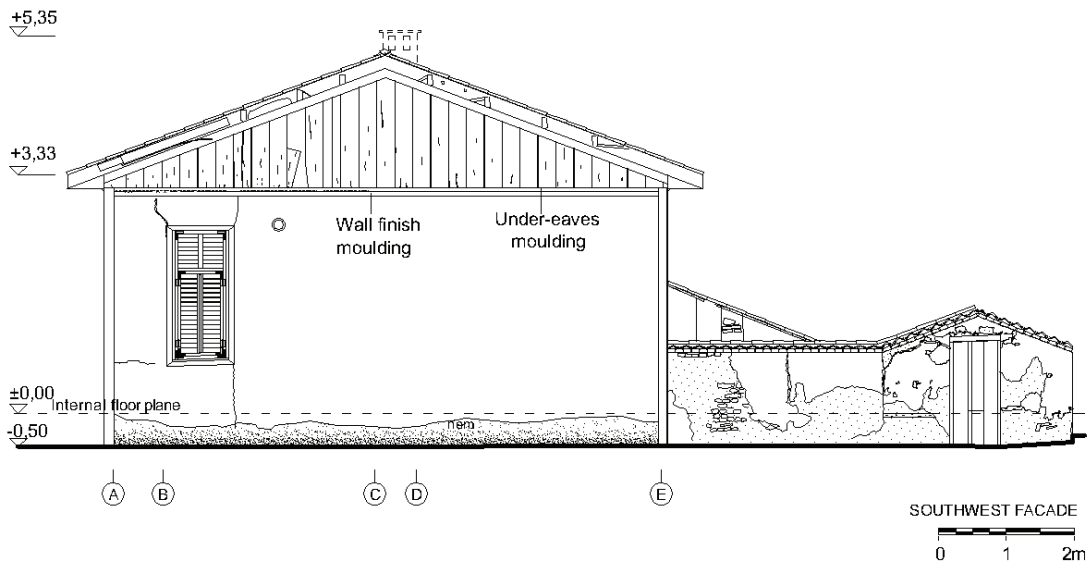

F. 16: Southwest Facade of the House (PA/22.12.2009)
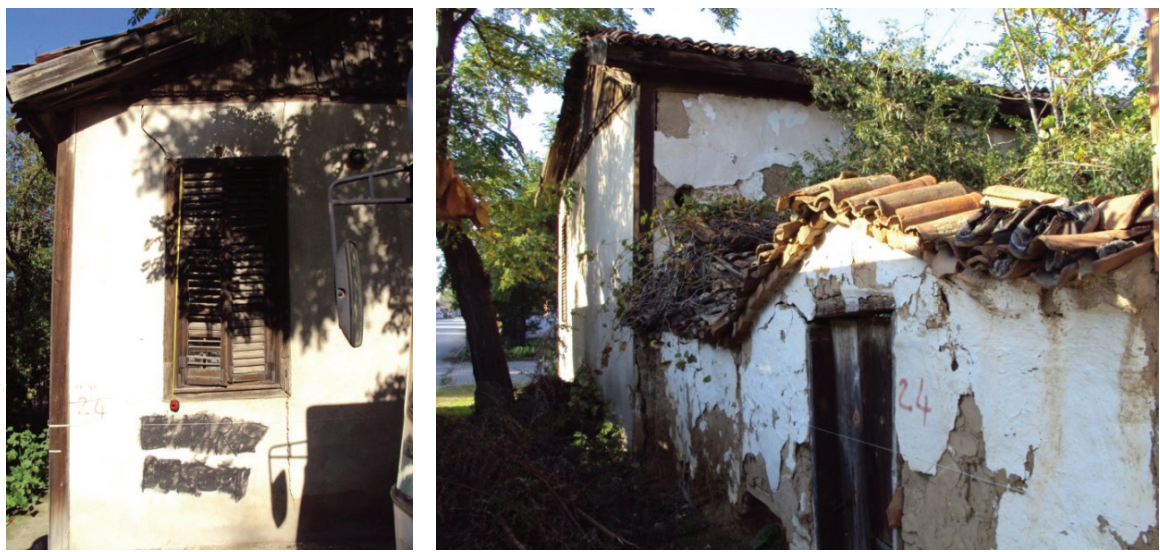

F. 17: Photographs showing the Southwest Facade of the House (PA/18. 11. 2009)

\section{Construction technique and material}

Posts are mounted on the timber sole plate placed on the basement wall. The main posts are located at the corners. In this construction system, there should be a thinner timber brace that assist and support the load transfer between the posts; however, when investigations were done on the surface where the plaster fell, these elements were not found. Probably during the renovation of the facade, in some areas the original construction technique was broken. Because timber brace under the fallen plaster are seen in the interior wall in the basement floor (F. 12, F. 18, F. 19).

Horizontal rails (girts) that act as connectors between the posts were used, and also at window lines. Although it is not visible because it is under plaster, the system should be connected with an upper beam again at the level where the ground floor 
ends (F. 18). Since most of the structural elements are under plaster, their size is unknown; however, as observed from the places where the plaster has fallen, the posts are $14-15 \mathrm{~cm}$, the under-window rail on the facade is $4.5 \mathrm{~cm}$ and it is $8 \mathrm{~cm}$ on the rear façade (F.12, F. 13). Oak trees were used in the structural elements. The exterior walls were filled with brick (22/11/5) and the interior walls were filled with adobe $(28 / 13 / 10)$. Plasters, whitewashes and paints were mentioned above. Pine which is resistant to external weather conditions was used in the doors and windows.

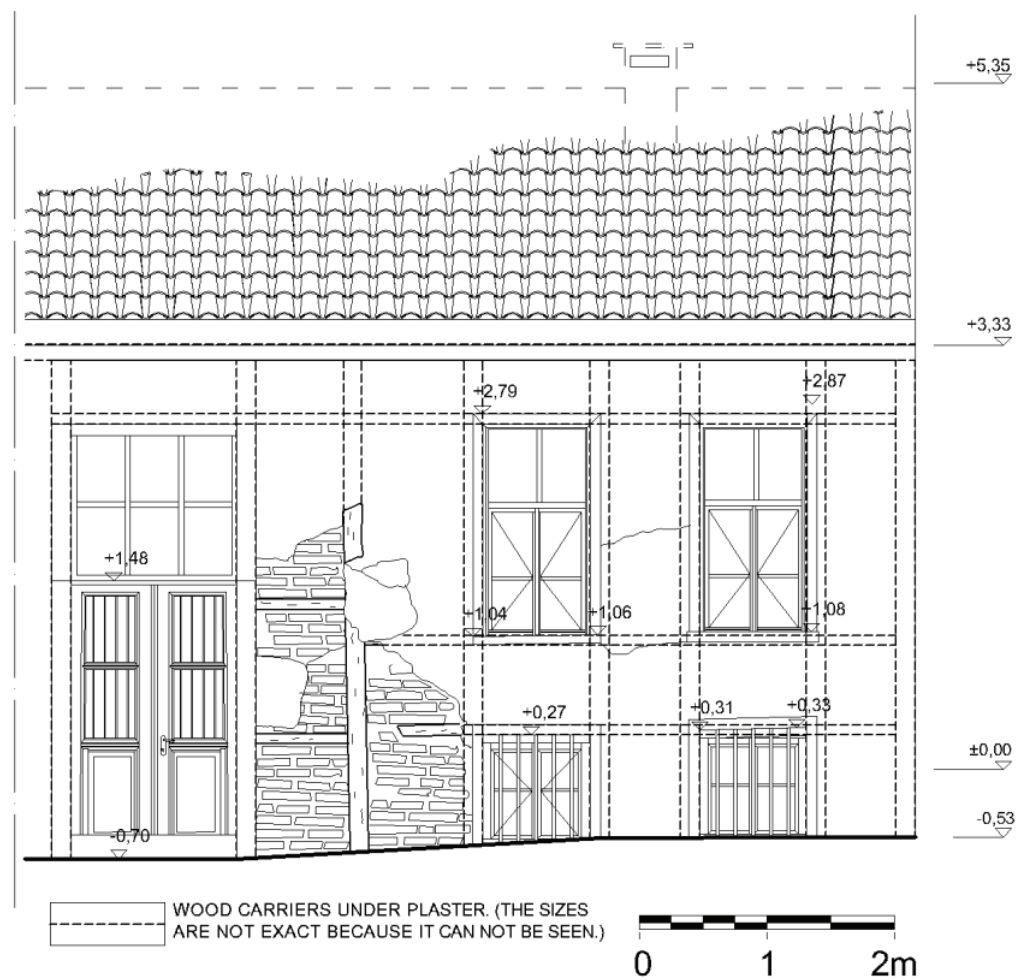

The timber braces were not drawn at facade because they were never seen. However, it is known that it is necessary for safe load transfer of structure system.

F. 18: Traces of Structural Elements on the Façade (PA/18. 11. 2009) 


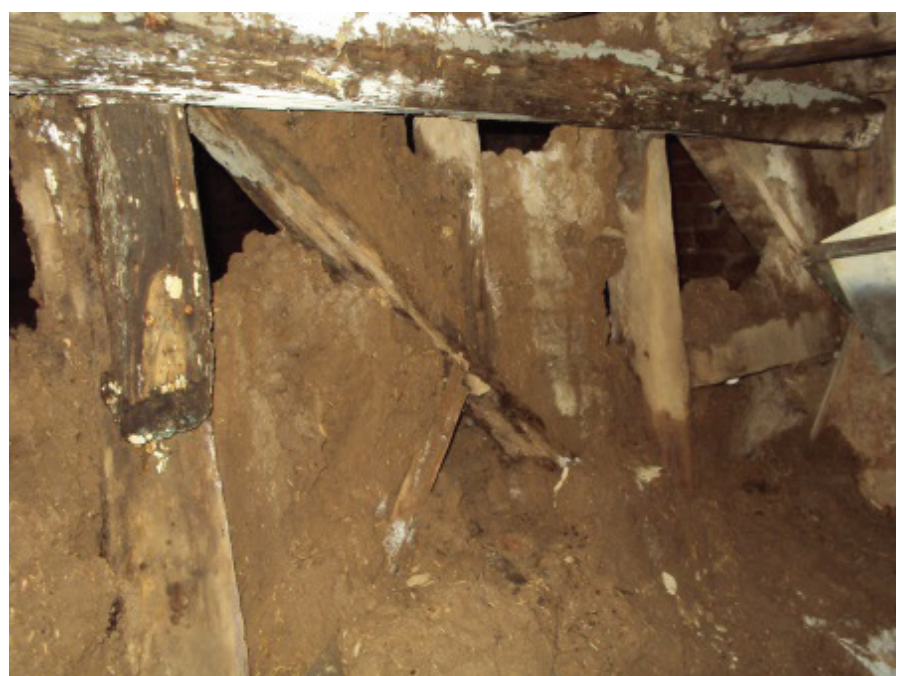

F. 19: Timber Structural Elements on the Intermediate Wall in the Basement Floor (It can be observed because of the plaster fall) (PA/18. 11. 2009)

\section{2019 Year Condition Determination}

The original function of the building was used as a dwelling house and the building became unusable after the death of the owner. Due to not providing today's expected level of comfort, the building remains non-functional and due to the lack of necessary maintenance and repair work because of financial inadequacies, the inability to reconcile progress between the heirs, etc. the building was gradually brought into the demolition process.

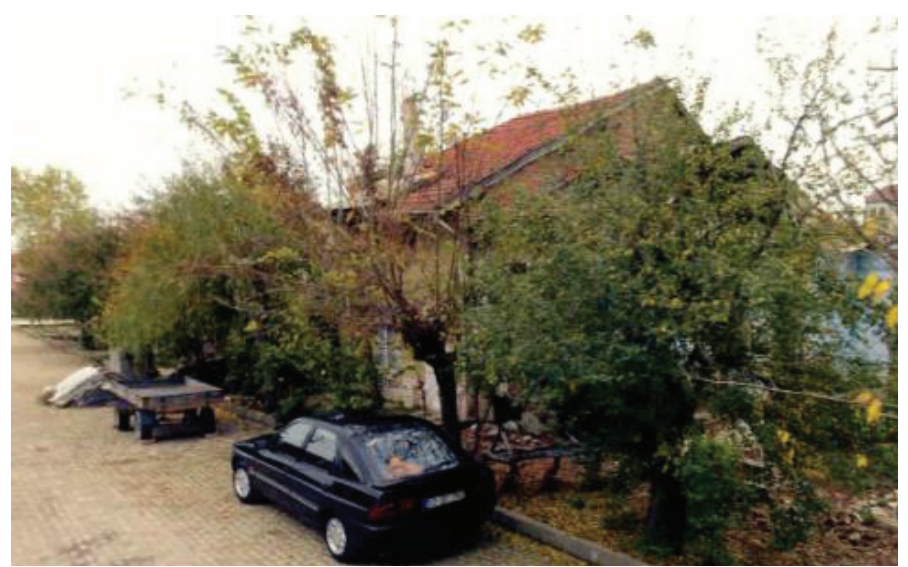

F. 20: Parcel of Housing in 2015 (Arabulan, "Kentsel Dönüşüm Kapsamında Kimliğin Yeniden Kazanımı: Edirne - Karaağaç Örneği,” 215). 
According to an examination conducted by Arabulan in 2015, only a part of its northern wall and roof residual remained (F. 20) ${ }^{32}$. According to the examination I conducted in 2019, it was found that the trees on the pavement on the northwest (entrance) facade of the building were cut down however they were present in 2009 and 2015. Except for a few trees in the backyard, other trees have not survived to the present day. Reforestation was done in the parcel. The original well in the backyard has been preserved but only a few rows of stones in the upper row have fallen (F. 21, F. 22).

There are no elements of the building left except the basic remains of the building, a few timber posts and filling materials. On the wall of the building the adjacent neighbour in Dilaverbey Street, there are traces of the wall and roof of the traditional house that was demolished. Apart from these, it can be said that there are no remains of the building as if the house never existed (F. 21, F. 22).

The Ministry of Culture and Tourism, Edirne Regional Board for the Preservation of Cultural Assets, has decided to continue the registration of the building as the 2nd group civil architecture with the date and number of resolutions dated 23.07.2019-6129 ${ }^{33}$.

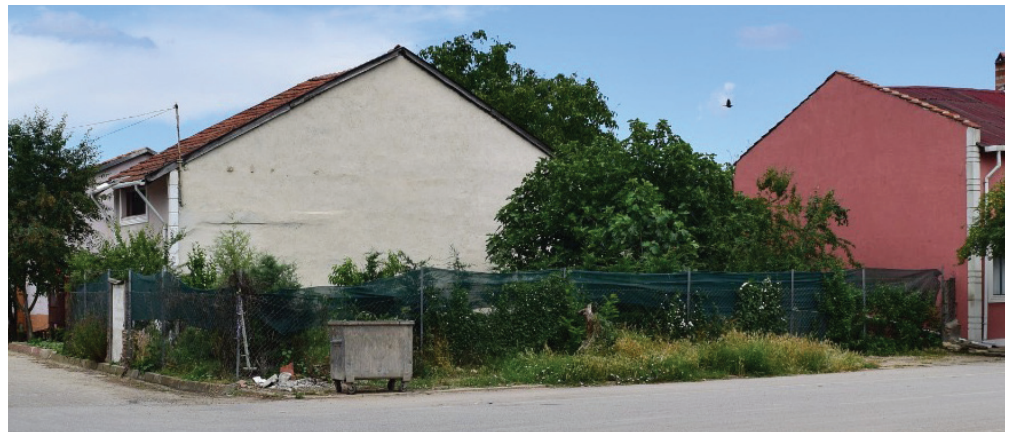

F. 21: Parcel of Housing in 2019 (PA/28.10.2019)

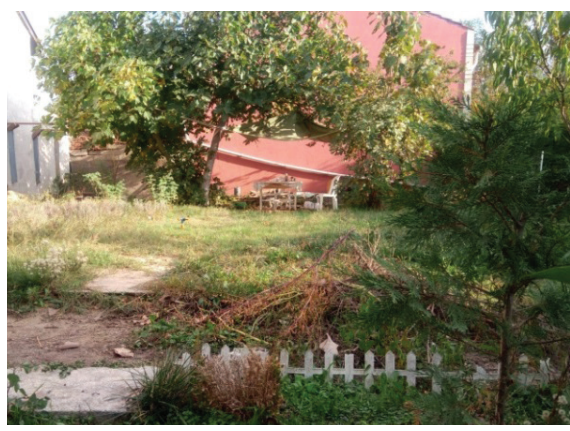

A Photo from Dilaverbey Street (PA/28.10.2019)

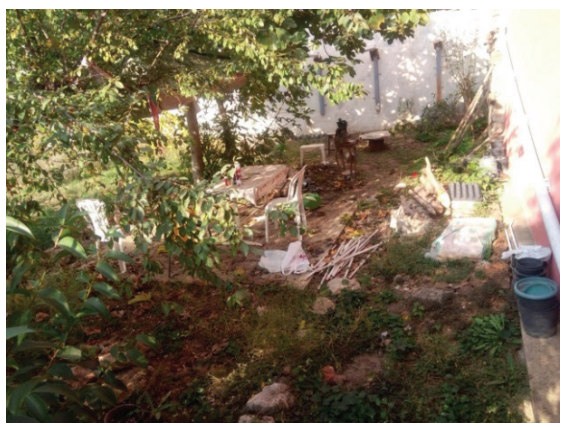

A Photo from Istiklal Street (PA/28.10.2019) F. 22: Photos of the Parcel from Dilaverbey and Istiklal Street

32 Selin Arabulan, "Kentsel Dönüşüm Kapsamında Kimliğin Yeniden Kazanımı: Edirne - Karaağaç Örneği””(PhD Thesis, Trakya University, 2015), 215.

33 Council for the Conservation of Cultural Property (CCCP), 23.07.2019-6129. 


\section{Evaluation}

The transformation of large families into small families, changing the preference of housing according to income status, the need for specialised spaces instead of multi-purpose spaces and the need for new spaces, shifting to modern living tools, migration from rural settlements to urban settlements etc. are the process of modernity and the reasons for the abandonment of traditional houses.

While the process of modernity causes these buildings to be abandoned on the one hand, it creates transformative and destructive effects in a way that threatens the traditional fabric with the urban unearned income, infrastructure and transportation demands brought by urbanization ${ }^{34}$.

In addition to these, reasons such as changes in the housing expectation due to age, the inability to reconcile of the heirs and the extension of the transfer process, etc. also cause traditional houses to become non-functional. The failure to maintain continuity in the maintenance and repair works caused the destruction of many of the architectural heritage which remained idle. Unfortunately, as in this building, many examples of this situation have been observed. Accordingly, it can be said that non-functional buildings are doomed to extinction.

\section{Suggestions}

Because documentation studies are completed before the destruction of the house, reconstruction can be suggested ${ }^{35}$. However, the crucial point in this situation is to establish a relationship of reasons and authenticity-reconstruction.

Considering charters about preservation, there is not a clear statement related to the reconstruction of cultural heritages in Carta Del Restauro and The Venice Charter (except for archaeological sites) ${ }^{36}$. According to the Convention Concerning the Protection of the World Cultural and Natural Heritage, reconstruction of buildings whose detailed and absolute documentation are made can be justified under particular conditions $^{37}$. The Burra Charter approves reconstruction under the conditions when re-

34 İlhan Tekeli, "Modernite Projesi İçinde Yapıların ve Kentsel Dokuların Korunması Sorunsalı," Her Dem Yeşil Yaprakl Bir Ağaç Cevat Erder'e Armağan, Ed. Güçhan Neriman Şahin (Ankara: ODTÜ Mimarlık Fakültesi Basım İşliği, 2003), 72-75.

35 By Arabulan, a study related to Karaagac urban transformation was prepared. According to this study, the suggestion of rehabilitation was presented for this region where there are many traditional houses. In this extent, consolidation, providing necessary equipment for functioning or adaptive reusing, improving infrastructure, redesigning urban furniture, appropriate landscape design will be (Arabulan, "Kentsel Dönüşüm Kapsamında Kimliğin Yeniden Kazanımı: Edirne - Karaağaç Örneği,"156). Whether the house which is examined should be included in urban transformation and reconstructed as infill needs to be discussed by specialists.

36 Zeynep Ahunbay, Tarihi Çevrede Koruma ve Restorasyon (İstanbul: Yapı Endüstri Merkezi Yayını, 2009), 148-151.

37 World Heritage Committee (WHC), Operational Guidelines for the Implementation of the World Heritage Convention (Paris: UNESCO World Heritage Centre, 2019),79-86. 
construction can be understood at a closer look, where there are sufficient documents and with the aim of reconstructing missing or damaged parts to bring it back to its old condition $^{38}$. If the Declaration of Dresden on the Reconstruction of Monuments Destroyed by War is summarized, the fact that an important monument having a cultural or political function was destroyed in war can be a justified reason for reconstruction. For reconstruction of this kind of monument, accurate documentation should be made before monument demolition ${ }^{39}$. Riga Charter states that copying of cultural heritage causes the transfer of historical traces inaccurately. However, it states that reconstruction can be found as appropriate if a cultural heritage is demolished as a result of a natural or human-based disaster has important aesthetic, symbolic or environmental values ${ }^{40}$ In a similar way, the Charter of Krakow 2000 advocates the reconstructions of buildings demolished as a result of war or natural disaster with the aim of cultural or social reasons (for creating social identity) ${ }^{41}$.

The ICOMOS Turkey Architectural Heritage Conservation Charter (2013) states that reconstruction can be made in situations where the demolition of a property has a cultural heritage feature which is in communal memory and in the situation of having sufficient data (If the place where cultural heritage and its surroundings did not change) ${ }^{42}$ In the 660 Number principle the decision of the High Council for the Conservation of Cultural Property reconstruction conditions are explained. According to this, if a cultural heritage is demolished because of any reason, its reconstruction can be made on the same parcel and sitting area with the same plan and facade features, height, construction technique and material. ${ }^{43}$

One of the first examples coming to mind is in Japan, about the authenticity and reconstruction relationship. There are reconstruction applications in two ways in Japan and one of them is to reconstruct with new materials accepted as revitalization. The other is the reconstruction with authentic/original material and construction technique in the extent of conservation ${ }^{44}$. This method was criticized for not coinciding with the

38 International Council on Monuments and Sites (ICOMOS), The Burra Charter: The Australia ICOMOS Charter for Places of Cultural Significance (Burwood: Australia ICOMOS Incorporated, 2013), 9.

39 ICOMOS, "Declaration of Dresden on the "Reconstruction of Monuments Destroyed by War" (The ICOMOS National Committee of the German Democratic Republic held a Symposium, Dresden, 15th to 19th November 1982).

40 Zeynep Ahunbay, Kültür Mirasını Koruma İlke ve Teknikleri (İstanbul: Yapı Endüstri Merkezi Yayını, 2019), 221-222.

41 Zeynep Ahunbay, "Yeniden Yapım (Rekonstrüksiyon) İçin Koşullar,” Mimarist 60 (2017), 32-37.

42 ICOMOS TURKEY, "ICOMOS Turkey Architectural Heritage Conservation Charter” (ICOMOS Turkey National Committee held meetings, Turkey, 30 May 2012 and 17 March 2013), 8, Access 18 November 2020, http://www.icomos.org.tr/?Sayfa=Icomostuzukleri\&dil=tr

43 High Council for the Conservation of Cultural Property, “660 nolu İlke Kararı-Taşınmaz Kültür Varlıklarının Gruplandırılması, Bakım ve Onarımları” (Ministry of Culture and Tourism, High Council for the Conservation of Cultural Property Held a Meeting, Ankara, 5 November 1999).

44 Süheyla Koç, “Japonya’da Bir Koruma Modeli Olarak Rekonstrüksiyon,” Mimarist 60 (2017), 64-65. 
Western conservation model is now accepted all over the world. In this conservation method, construction technique and culture are preserved not the building itself. ${ }^{45}$

In Riga Charter, Declaration of Dresden and the Charter of Krakow 2000, it is emphasized that reconstruction is made in the situation of cultural heritage demolition as a result of factors such as natural disaster or war. As a consensus, the reconstruction of a cultural heritage is considered appropriate when the cultural heritage has a role in the societies identity and symbolic value and is demolished by a disaster. ${ }^{46}$

Even in the situation of disasters like war, natural disasters, there are many debatable subjects about reconstruction such as what will be preserved untouched (preserving as a war memory), what will be reconstructed, who will be responsible, in which conditions reconstruction should be made. In addition, for how long should the waiting period be between destruction and reconstruction, when the destructed heritage may be forgotten and thus when reconstruction will be accepted as unnecessary should be considered. Whether reconstruction is a message for peace and cooperation, whether a demolished cultural heritage in the world heritage list of UNESCO should be removed from the list when it is reconstructed, whether reconstruction has reasonable grounds for educational purposes and so forth should be also taken into consideration. ${ }^{47}$

Although it is not certain for specialised scientists whether a cultural heritage should be demolished because of war, natural disaster etc. to make a decision about reconstruction. The subject compromised by the conservation authorities is to make reconstruction depending upon the precise and continuous documents such as building remains, building survey, photographs, visual and written archive if the reconstruction decision is to be made.

45 Deniz Mazlum, “Koruma Kuramının Mimari Rekonstrüksiyona Bakışı,” Mimarlık 380 (2014), 75.

46 Benjamin Isakhan and Sofya Shahab, “The Islamic State's Destruction of Yezidi Heritage: Responses, Resilience and Reconstruction after Genocide," Journal of Social Archaeology 20(1) (2020), 3; Benjamin Isakhan and Lynn Meskell, "UNESCO's Project to 'Revive the Spirit of Mosul': Iraqi and Syrian Ppinion on Heritage Reconstruction after the Islamic State," International Journal of Heritage Studies 25(11) (2019), 1192; Tomasz Jele'nski, "Practices of Built Heritage Post-Disaster Reconstruction for Resilient Cities," Buildings 8(53) (2018), 17; Jhon Bold, "Introduction: Reconstruction: The Built Heritage Following War and Natural Disaster," Authentic Reconstruction: Authenticity, Architecture and the Built Heritage, Ed. John Bold, Peter Larkham, Robert Pickard (London, NewYork: Bloomsbury Publishing, 2018), 1-2; Roha Khalaf, "A Viewpoint on the Reconstruction of Destroyed UNESCO Cultural World Heritage Sites," International Journal of Heritage Studies 23 (3) (2017), 261-262; WHC, "State of Conservation of World Heritage Properties," Decision : 39 COM 7 (Bonn: 39th session of the World Heritage Committee, 2015), 10-53; Ahunbay, "Yeniden Yapım (Rekonstrüksiyon) İçin Koşullar", 32-37; Zeynep Eres, "Koruma Biliminin Açmazı: Politik Söylemin Aracı Olarak Rekonstrüksiyonlar,” Mimarist 60 (2017), 77-84; Ahmet Ersen, “Türkiye'de Tarihi Çevre Koruma(ma) Tarihi ve Rekonstrüksiyon Üzerine Düşünceler," Restorasyon ve Konservasyon Çalışmaları Dergisi 12 (2014), 23; ICOMOS TURKEY, “ICOMOS Turkey Architectural Heritage Conservation Charter,” 8.

47 Isakhan and Shahab, “The Islamic State's Destruction of Yezidi Heritage: Responses, Resilience and Reconstruction after Genocide," 3; Benjamin Isakhan and Lynn Meskell, "UNESCO's Project to 'Revive the Spirit of Mosul': Iraqi and Syrian Opinion on Heritage Reconstruction after the Islamic State," International Journal of Heritage Studies 25(11) (2019), 1189-1204; Selcen Coşkun, "Miras Yapıların Eğitici Değeri Yeniden Yapımları Haklı Çıkarır mı? İngiltere'den Bir Örnek: Barley Hall,” Mimarist 60 (2017), 46-56; Vildan Yarlıgaş, “Almanya'da Mimari Rekonstrüksiyona Bakış: Üç Dönem, Üç Örnek,” Mimarist 60 (2017), 38-45. 
The fact that reconstruction is allowed under certain conditions should not be an obstacle to preserve cultural heritage. For a reconstruction decision, the building should be in a state of demolition. It is not accepted that a cultural heritage is demolished purposely for any reasons such as unearned income, expectation of canceling registration, the easiness of new a construction. ${ }^{48}$ Also, if the reconstruction is made inaccurately, it may cause construction of buildings which carry just economic value and which is meaningless, lack of Genius Loci. ${ }^{49}$

Reconstruction of the traditional house which is the subject of this article can be made on the same parcel with the same plan, facade and ornamental features through original material and techniques. However, as mentioned above, the reason for the demolition of the building is not caused by a natural disaster or war. The demolition of the building has not created social trauma or the building has no outstanding universal value and symbolic value.

This demolished cultural heritage can be said to have an environmental value for Karaagac settlement in the past. It should be open to discuss whether environmental value is enough to decide on reconstruction. If this decision is made, it needs to provide an environmental analysis, synthesis and suggestions in a holistic way for Karaagac to create its environmental value. This is another research subject that should be carried out as teamwork.

For the conservation authorities, how reconstruction should be made is not a certain decision in the situation of cultural heritage destruction. Therefore, what should be done before losing a cultural heritage needs to be focused on. Continuous maintenance and repair is the wisest way that can save a cultural heritage from demolition. The continuity of maintenance and repair can be enabled only through usage of cultural heritage.$^{50}$ It is known that the buildings reused through adaptive methods or the buildings sustaining their original function with revisions are conserved. Many examples may be given related to this subject from our country or abroad.

48 Yıldız Salman, “Kaygan Zeminde Koşarken: Yeniden İnşa Edilen Mecidiyeköy Likör Fabrikası’nın Düşündürdükleri,” Mimarlık 407 (2019), 16-19; Eres, "Koruma Biliminin Açmazı: Politik Söylemin Aracı Olarak Rekonstrüksiyonlar," 77-84.

49 Mazlum, "Koruma Kuramının Mimari Rekonstrüksiyona Bakışı," 75.

50 Mehr and Wilkinson, "The Importance of Place and Authenticity in Adaptive Reuse of Heritage Buildings," 689-690; Bottero, D’Alpaos and Oppio, "Ranking of Adaptive Reuse Strategies for Abandoned Industrial Heritage in Vulnerable Contexts: A Multiple Criteria Decision Aiding Approach," 1; Vardopoulos, "Critical Sustainable Development Factors in the Adaptive Reuse of Urban Industrial Buildings: A Fuzzy DEMATEL Approach," 2; Plevoets and Sowińska-Heim, "Community Initiatives as a Catalyst for Regeneration of Heritage Sites: Vernacular Transformation and Its Influence on the Formal Adaptive Reuse Practice," 128-129; Pongsermpol and Upala, "Impacts of Adaptive Reuse of Heritage Buildings Converted to Small Hotels in Bangkok," 69; Hanafi, et al. "Essential Entities towards Developing an Adaptive Reuse Model for Organization Management in Conservation of Heritage Buildings in Malaysia," 265; Sugden, "The Adaptive Reuse of Industrial Heritage Buildings: A Multiple-Case Studies Approach,” 11-110. 


\begin{tabular}{|c|c|}
\hline \multicolumn{2}{|c|}{ Cultural Heritage Examples Conserved through Usage } \\
\hline $\begin{array}{l}\text { Name: Wuyuan Skywells Hotel } \\
\text { Location: Wuyuan County, Republic of China, } \\
\text { Orijginal function : Inn } \\
\text { New function : Hotel } \\
\text { Date of construction About } 300 \text { years ago } \\
\text { Date of adaptive reuse : } 2017 \\
\text { Awards: ICONIC award, a RED DOT award, and an A }\end{array}$ & AF award, shortlisted by the INSIDE Awards \\
\hline $\begin{array}{l}\text { The facade of the building has been conserved in its } \\
\text { original state. } \\
\text { (Photography: Marc Goodwin, thespaces.com) }\end{array}$ & $\begin{array}{l}\text { Inner court of the hotel (Photography: Marc } \\
\text { Goodwin, thespaces.com) }\end{array}$ \\
\hline $\begin{array}{l}\text { Name: Nevill Holt Opera Theatre } \\
\text { Location: Harborough District of Leicestershire, Engla } \\
\text { Orijginal function : Country houses } \\
\text { New function : Opera Theatre } \\
\text { Date of construction: } 1288 \\
\text { Date of adaptive reuse : } 2018 \\
\text { Awards: RIBA East Midlands Award 2019, RIBA E }\end{array}$ & $\begin{array}{l}\text { lands Conservation Award 2019, RIBA Ea } \\
\text { vard } 2019^{52} \text {. }\end{array}$ \\
\hline
\end{tabular}

51 The Spaces, "A 300-year-old ruin is restored as a hotel in rural China," access 21 November 2020, https:// thespaces.com/a-300-year-old-ruin-is-restored-as-a-hotel-in-rural-china/2/; anySCALE, "The Wuyuan Skywells Hotel," access 21 November 2020, http://anyscale.cn/our-stories/wuyuan-skywells-hotel/; Architektur Zeitung, "Wuyuan Skywells Hotel by anySCALE Architecture Design," access 21 November 2020, https:// www.architekturzeitung.com/architecture-magazine/3473-wuyuan-skywells-hotel-by-anyscale-architecture-design

52 RIBA Architecture, "Nevill Holt Opera," access 21 November 2020, https://www.architecture.com/ awards-and-competitions-landing-page/awards/riba-regional-awards/riba-east-midlands-award-winners/2019/nevill-holt-opera; Internet Archive, "Nevill Holt, Corby, England," access 21 November 2020, https://web.archive.org/web/20120215112926/http://www.parksandgardens.ac.uk/component/option,com_ parksandgardens/task,site/id,5275/tab,history/Itemid,/ 


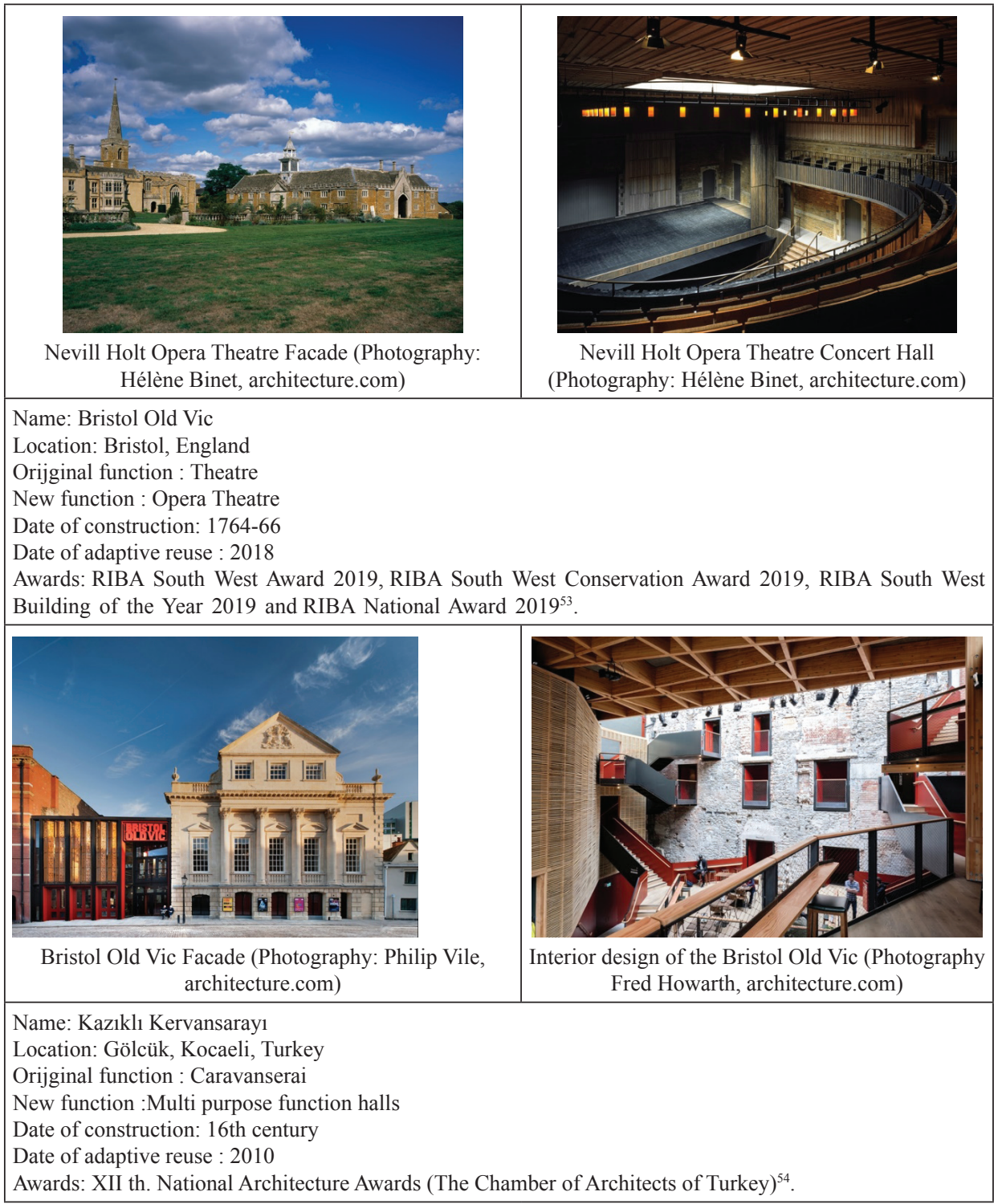

53 RIBA Architecture, "Bristol Old Vic,", access 21 November 2020, https://www.architecture.com/ awards-and-competitions-landing-page/awards/riba-regional-awards/riba-south-west-award-winners/2019/ bristol-old-vic; "Historic England, The Theatre Royal," access 21 November 2020, https://historicengland. org.uk/listing/the-list/list-entry/1209703

54 Mimarlar Odası, XII. /2010 Ulusal Mimarlı Sergisi ve Ödülleri, Yapılar, Projeler, Fikirler (Ankara: Mimarlar Odası Yayını, 2010), 50-55. 


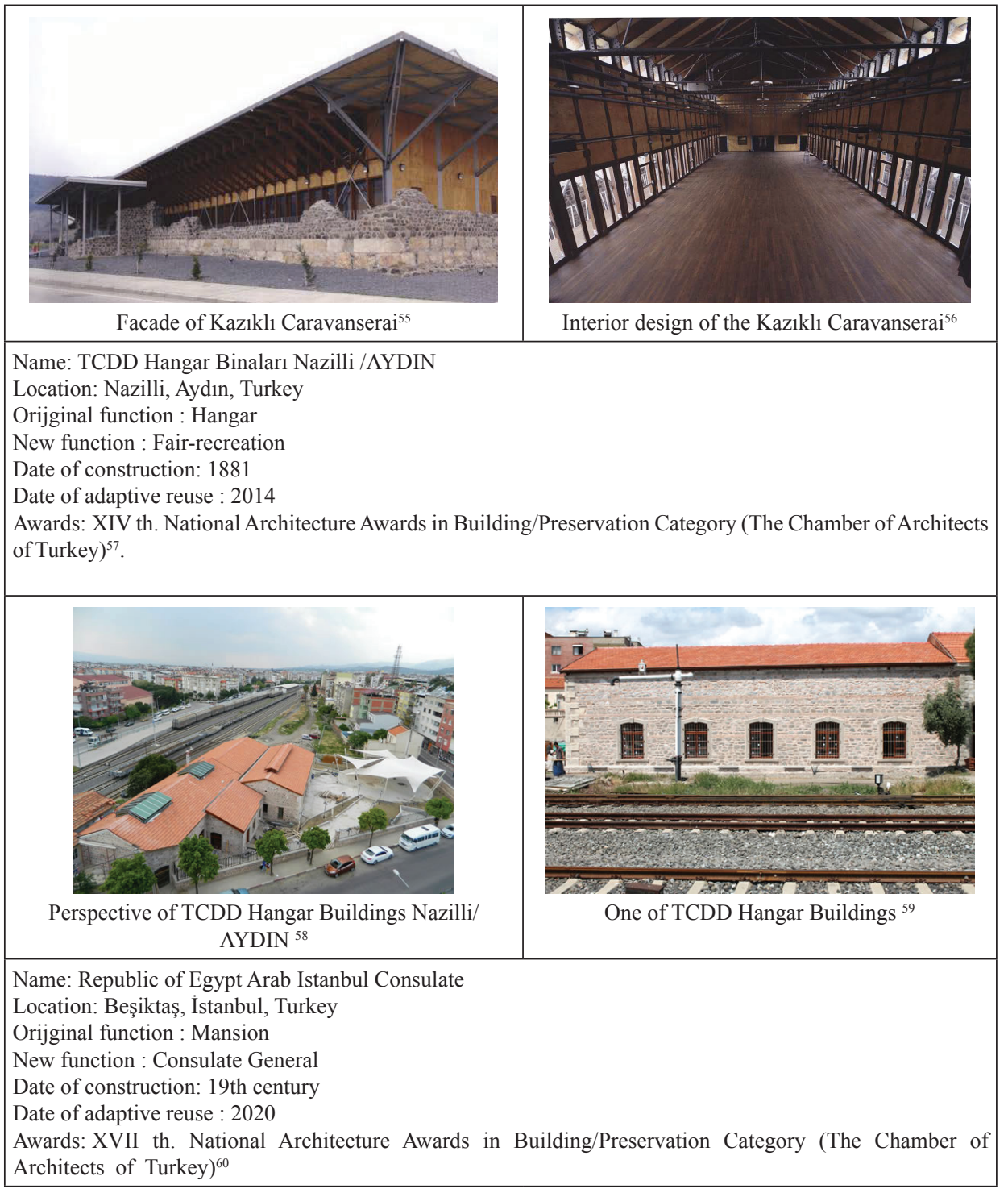

55 Mimarlar Odas1, XII. /2010 Ulusal Mimarlı Sergisi ve Ödülleri, Yapılar, Projeler, Fikirler 50-55.

56 Mimarlar Odası, XII. $/ 2010$ Ulusal Mimarlk Sergisi ve Ödülleri, Yapılar, Projeler, Fikirler 50-55.

57 The Chamber of Architects of Turkey, "Ulusal Mimarlık Sergisi ve Ödülleri," access 15 November 2020, http://mo.org.tr/ulusalsergi/index.cfm?sayfa=YDK_TCDD

58 "Ulusal Mimarlık Sergisi ve Ödülleri,"

59 "Ulusal Mimarlık Sergisi ve Ödülleri,"

60 The Chamber of Architects of Turkey, "Ulusal Mimarlık Sergisi ve Ödülleri," access 15 November 2020, http://mo.org.tr/ulusalsergi/index.cfm?sayfa=YDK_M 


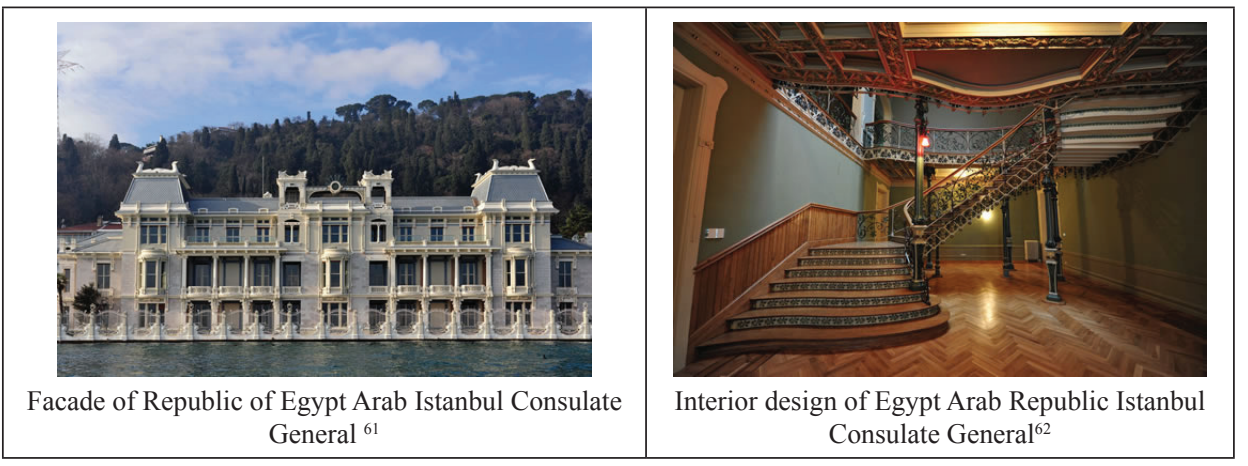

\section{Conclusion}

The destruction of a cultural heritage is an irreversible loss for society. Therefore, what needs to be done first is to prevent the destruction of these buildings that play a role in the formation of social identity. For this purpose, in order to ensure the ownership/adoption of a cultural heritage, it is necessary to analyse it first and determine its values. Then it is necessary to document, register and develop a sustainable preservation policy. Transferring cultural heritage to future generations can be through the creation of sustainable preservation policies and the adoption by society.

Examples of civil architecture, built to meet the need for housing in the past are considered to be environmentally valuable buildings that play an active role in the formation of the historical environment. It is not right to exclude them from acts of preservation by considering them as singular and suggesting that these buildings have no aesthetic value. Each of these buildings has a folkloric value by reflecting the customs of the society and the daily life of that period; a historical evidential value by reflecting the construction technique and material of a period and history; and an age value by its age. Apart from these, it can carry the authenticity value, homogeneity value, functional value and memory value according to the qualities it carries.

When all these values are taken into consideration, studies should be carried out to ensure the continuity of preservation as well as registering these environmentally valuable buildings as cultural assets that need to be preserved. The first step to be taken for sustainable conservation understanding is to transfer the importance of the concept of 'preserving cultural heritage' to the students at primary school level, to enable the students to adopt it by continuing this education in later periods, to instil the awareness that preserving a cultural heritage is a social duty. Individuals who have embraced the importance of preserving their cultural heritage can solve the dilemma between unearned income-preservation that they face at any stage of their life in a

61 "Ulusal Mimarlık Sergisi ve Ödülleri."

62 "Ulusal Mimarlık Sergisi ve Ödülleri." 
more accurate way. Nevertheless, consciousness alone may not be enough at this point. In addition to preservation awareness, it is necessary to approach the situation in terms of professional ethical values. From this point of view, the problem enters into a more general framework and becomes an unearned income-ethical fight, which is now the main problem of the architectural production process that constitutes the building environment.

Since maintenance and repair works are not carried out, the buildings that are in the process of collapse are also affected by this unearned income-ethics fight. Because the restoration costs are quite high, this makes it more attractive to have these buildings destroyed by being left to their own state than to be repaired. In this case, it can be said that maintaining the parcel registration of a demolished building is the right decision and could be a deterrent for property owners who feel that the registration would be dropped by demolishing their traditional house. In the event of the demolition of the registered building, the operation of the land for parking purposes is another unearned income gate and the use of the land for this and similar purposes should never be allowed.

If the new building is allowed in the parcel, an element which may damage the preservation policies may occur. However, the owner who approaches with the idea of 'new building can be built' may not consciously repair the building or he can even demolish it. Reconstruction on the registered parcel can be offered as a proposal. However, whether this application should be needed or not is a debatable subject as mentioned above.

Even if reconstruction of demolished cultural heritage is made, it cannot be mentioned as a building having an historical value. For this reason, it is essential that cultural heritage be treated with a sustainable preservation approach. It is accepted as a sustainable preservation policy for reusing heritage or updating it functionally to keep up with today's conditions. The maintenance and repair of the buildings in continuous use will be carried out regularly and so the continuity of the preservation will be ensured.

As a sustainable preservation method, these buildings should be preserved and maintained, and in order to achieve this, arrangements should be made to ensure the comfort conditions of today. However, the exploitation of the building under the name of reusing or functional update is also not correct. The point to be considered at this point is the balance of preservation and use. For this balance, a multi-discipline research should be carried out with engineers of construction, mechanic and electrical, art historian and an architect specialised in conservation-restoration. In common solutions, both users' demands and preserving authenticity value of the building should be taken into consideration. 
Peer-review: Externally peer-reviewed.

Conflict of Interest: The author has no conflict of interest to declare.

Grant Support: The author declared that this study has received no financial support.

Hakem Değerlendirmesi: Dış bağımsız.

Çıkar Çatışması: Yazar çıkar çatışması bildirmemiştir.

Finansal Destek: Yazar bu çalışma için finansal destek almadığını beyan etmiştir.

\section{References/Kaynakça}

Ahunbay, Zeynep. "Yeniden Yapım (Rekonstrüksiyon) İçin Koşullar.” Mimarist 60 (2017): 32-37.

Ahunbay, Zeynep. Kültür Mirasını Koruma İlke ve Teknikleri. İstanbul: Yapı Endüstri Merkezi Yayın1, 2019.

Ahunbay, Zeynep. Tarihi Çevrede Koruma ve Restorasyon. İstanbul: Yapı Endüstri Merkezi Yayını, 2009 .

AnySCALE. "The Wuyuan Skywells Hotel.” Access 21 November 2020. http://anyscale.cn/ourstories/wuyuan-skywells-hotel/

Arabulan, Selin. "Kentsel Dönüşüm Kapsamında Kimliğin Yeniden Kazanımı: Edirne - Karaağaç Örneği." PhD Thesis, Trakya University, 2015.

Architektur Zeitung. "Wuyuan Skywells Hotel by anySCALE Architecture Design." Access 21 November 2020. https:/www.architekturzeitung.com/architecture-magazine/3473-wuyuanskywells-hotel-by-anyscale-architecture-design

Baedecker, Karl. Konstantinopel, Balkanstaaten, Kleirasien, Archipel, Cypern. Leipzig: Verlag Von Karl, 1914.

Bold, Jhon. "Introduction: Reconstruction: The Built Heritage Following War and Natural Disaster," Authentic Reconstruction: Authenticity, Architecture and the Built Heritage. Edited by John Bold, Peter Larkham, Robert Pickard. London, NewYork: Bloomsbury Publishing, 2018, 1-25.

Bottero, Marta, Chiara D'Alpaos and Alessandra Oppio. "Ranking of Adaptive Reuse Strategies for Abandoned Industrial Heritage in Vulnerable Contexts: A Multiple Criteria Decision Aiding Approach.” Sustainability 11 (2019): 1-18.

Budak, Mustafa. "Paris Barış Konferansı Sürecinde (22 Mart-10 Nisan 1922) İtilâf Devletlerine Sunulan Batı Trakya Hakkında İki Muhtıra.” Türkiyat Mecmuası, 27(2) (2017): 101-117.

Bulut, Sedef. “Balkan Savaşları'ndan Lozan'a Batı Trakya Meselesi ve Mustafa Kemal Atatürk'ün Bat1 Trakya Politikası”. Gazi Türkiyat Dergisi 1(3) (2008): 83-96.

Coşkun, Selcen. "Miras Yapıların Eğitici Değeri Yeniden Yapımları Haklı Çıkarır mı? İngiltere'den Bir Örnek: Barley Hall.” Mimarist 60 (2017): 46-56.

Council for the Conservation of Cultural Property (CCCP), 23.07.2019-6129.

Darkot, Besim. “Edirne, Coğrafi Giriş,” Edirne’nin 600. Fethi Yıl Dönümü Armağan Kitabı. Ankara: Türk Tarih Kurumu Basımevi, 1993, 1-12.

Dikmen, Belgin, Çiğdem. "Sustainability of Traditional Houses: Two Mansions Protected Through Adaptive Reuse in Yozgat." Gazi University Journal of Science Part B: Art, Humanities, Design And Planning 2(1) (2013): 69-87. 
Eldem, Hakk1, Sedat. Türk Evi Plan Tipleri. İstanbul: İTÜ Mimarlık Fakültesi Yayını, 1968.

Emekligil, Erdoğu, Rabia. Geçmişin İzinde Karaă̆aç. İstanbul: Edirne Valiliği Kültür Yayınları, 2013.

Erdoğan, Nevnihal. "Edirne'de Mimarlığa Bakış,” Türkiye’de Mimarlık, Yıldız Buluşmaları 06 Toplantıları. İstanbul: Umut Matbaası/Çanakakle Seramik Kalebodur, 2007, 23-33.

Erdoğan, Nevnihal. "Edirne'nin Eski Dış Bölgesi Karaagaç’ta Osmanlı Döneminde Yaşayan Azınlıkların Konutları.” Yapı Dergisi 230 (2001): 57-66.

Erdoğan, Nevnihal. Edirne Kentinde Konut Yerleşimlerinin Fiziksel ve Sosyal Yapısının Kültür Bağlamında Değerlendirilmesi. Edirne: Trakya Üniversitesi Rektörlüğü Yayını No:67, 2006.

Eres, Zeynep. "Koruma Biliminin Açmazı: Politik Söylemin Aracı Olarak Rekonstrüksiyonlar." Mimarist 60 (2017): 77-84.

Ersen, Ahmet. "Türkiye'de Tarihi Çevre Koruma(ma) Tarihi ve Rekonstrüksiyon Üzerine Düşünceler.” Restorasyon ve Konservasyon Çalışmaları Dergisi 12 (2014): 3-25.

Grcheva, Olgica. “Cultural Benefits of Former Military Buildings' Reuse: Public Room, Skopje, Republic of North Macedonia." TOLEHO 1(2) (2019):76-84.

Hanafi, Mohd, Hanizun, Arman Abdul Razak, Zul Zakiyudin Abdul Rashid and Mohd Umzarulazijo Umar. "Essential Entities towards Developing an Adaptive Reuse Model for Organization Management in Conservation of Heritage Buildings in Malaysia." E-BPJ 3(7) (2018): 265-276.

High Council for the Conservation of Cultural Property. "660 nolu İlke Kararı-Taşınmaz Kültür Varlıklarının Gruplandırılması, Bakım ve Onarımları.” Ministry of Culture and Tourism, High Council for the Conservation of Cultural Property held a meeting, Ankara, 5 November 1999.

Historic England. “The Theatre Royal.” Access 21 November 2020. https://historicengland.org.uk/ listing/the-list/list-entry/1209703

ICOMOS Turkey. "ICOMOS Turkey Architectural Heritage Conservation Charter." ICOMOS Turkey National Committee held meetings, Turkey, 30 May 2012 and 17 March 2013, 1-11, Access: 18 November 2020 http://www.icomos.org.tr/?Sayfa=Icomostuzukleri\&dil=tr

ICOMOS. "Declaration of Dresden on the "Reconstruction of Monuments Destroyed by War." The ICOMOS National Committee of the German Democratic Republic held a Symposium, Dresden, 15th to 19th November 1982.

International Council on Monuments and Sites (ICOMOS). The Burra Charter: The Australia ICOMOS Charter for Places of Cultural Significance. Burwood: Australia ICOMOS Incorporated, 2013.

Internet Archive. "Nevill Holt, Corby, England.” Access 21 November 2020. https://web.archive. org/web/20120215112926/http://www.parksandgardens.ac.uk/component/option,com parksandgardens/task,site/id,5275/tab,history/Itemid,/

Isakhan, Benjamin and Lynn Meskell. 'UNESCO's project to 'Revive the Spirit of Mosul': Iraqi and Syrian Opinion on Heritage Reconstruction after the Islamic State." International Journal of Heritage Studies 25(11) (2019): 1189-1204.

Isakhan, Benjamin and Sofya Shahab. "The Islamic State's Destruction of Yezidi Heritage: Responses, Resilience and Reconstruction after Genocide." Journal of Social Archaeology 20(1) (2020): 3-25.

İnalcık, Halil. "Edirne'nin Fethi (1361).” Edirne'nin 600. Fethi Yıl Dönümü Armă̆an Kitabı. Ankara: Türk Tarih Kurumu Basımevi, 1993, 137-160. 
İslamoğlu, Özge. "Tarihi Yapıların Yeniden Kullanılmasında Yapı-İşlev Uyumu: Rize Müzesi Örneği." Journal of History Culture and Art Research 7(5) (2018): 510-523.

Jele'nski, Tomasz. "Practices of Built Heritage Post-Disaster Reconstruction for Resilient Cities." Buildings 8 (53) (2018):1-20.

Kansu, Aziz, Şevket. "Edirne'nin Tarihöncesine Ait Araştırmalar," Edirne'nin 600. Fethi Yll Dönümü Armağan Kitabı. Ankara: Türk Tarih Kurumu Basımevi, 1993, 13-20.

Khalaf, Roha. "A viewpoint on the reconstruction of destroyed UNESCO Cultural World Heritage Sites.” International Journal of Heritage Studies 23 (3) (2017): 261-274.

Koç, Süheyla. “Japonya'da Bir Koruma Modeli Olarak Rekonstrüksiyon.” Mimarist 60 (2017): 58-66.

Kuyrukçu, Yıldız, Emine, Zafer Kuyrukçu ve Dicle Aydın. "Geleneksel Konya Evlerinden Fuat Anadolu Evi'nin Yeniden Kullanım Bağlamında Değerlendirilmesi.” Artium 3 (1) (2015): 79-91.

Kütükoğlu, Mübahat. "Osmanlı İktisad Tarihi Bakımından Konsol Raporlarının Ehemmiyeti ve Kıymeti.” Güney Doğu Avrupa Araştırmaları Dergisi 10(99) (1983): 151-166.

Mazlum, Deniz. "Koruma Kuramının Mimari Rekonstrüksiyona Bakışı.” Mimarlık 380 (2014): 72-77.

Mehr, Yazdani, Shabnam and Sara Wilkinson. "The importance of place and authenticity in adaptive reuse of heritage buildings." International Journal of Building, Pathology and Adaptation 38(5) (2020): 689-701.

Meral, Aslı. “19. Yüzyıl Mimarlığında Karaağaç İstasyon Kompleksi.” M.A. Thesis, Trakya University, 2016.

Mimarlar Odası. XII. /2010 Ulusal Mimarlık Sergisi ve Ödülleri, Yapılar, Projeler, Fikirler. Ankara: Mimarlar Odası Yayını, 2010.

Misırl1, Nilay, Tuğba Kiper ve Aslı Korkut. "Doğal ve Kültürel Kent Kimliklerinin Belirlenmesi: Edirne İli Karaağaç Mahallesi Örneği.” Journal of Bartın Faculty of Forestry 21 (1) (2019): 52-65.

Plevoets Bie and Julia Sowińska-Heim. "Community Initiatives as a Catalyst for Regeneration of Heritage Sites: Vernacular Transformation and Its Influence on the Formal Adaptive Reuse Practice." Cities 78 (2018): 128-139.

Pongsermpol Chotewit and Prapatpong Upala. "Impacts of Adaptive Reuse of Heritage Buildings Converted to Small Hotels in Bangkok." Asian Journal of Quality of Life (AjQoL) 3(13) (2018): 69-79.

RIBA Architecture. "Bristol Old Vic.” Access 21 November 2020. https://www.architecture.com/ awards-and-competitions-landing-page/awards/riba-regional-awards/riba-south-west-awardwinners/2019/bristol-old-vic

RIBA Architecture. "Nevill Holt Opera.” Access 21 November 2020. https://www.architecture.com/ awards-and-competitions-landing-page/awards/riba-regional-awards/riba-east-midlands-awardwinners/2019/nevill-holt-opera

Salman, Yıldız. “Kaygan Zeminde Koşarken: Yeniden İnşa Edilen Mecidiyeköy Likör Fabrikası'nın Düşündürdükleri.” Mimarlık 407 (2019): 16-19.

Sugden, Evan. "The Adaptive Reuse of Industrial Heritage Buildings: A Multiple-Case Studies Approach.” The degree of Master of Arts, University of Waterloo, 2018. 
Tekeli, İlhan. "Modernite Projesi İçinde Yapıların ve Kentsel Dokuların Korunması Sorunsalı." Her Dem Yeşil Yapraklı Bir Ă̆aç Cevat Erder'e Armağan. Edited by Güçhan Neriman Şahin. Ankara: ODTÜ Mimarlık Fakültesi Basım İşliği, 2003, 72-75.

The Chamber of Architects of Turkey. "Ulusal Mimarlık Sergisi ve Ödülleri.” Access 15 November 2020. http://mo.org.tr/ulusalsergi/index.cfm?sayfa=YDK_TCDD

The Chamber of Architects of Turkey. "Ulusal Mimarlık Sergisi ve Ödülleri.” Access 15 November 2020. http://mo.org.tr/ulusalsergi/index.cfm?sayfa=YDK_M

The Spaces. "A 300-year-old ruin is restored as a hotel in rural China.” Access 21 November 2020. https://thespaces.com/a-300-year-old-ruin-is-restored-as-a-hotel-in-rural-china/2/

Türk Tarih Kurumu. Düstur 3.Terpip- Lozan Sulh Muahedenamesinin Kabulüne Dair Kanunlar. 5. cilt. İstanbul: Necmi İstikbal Matbaası, 1931.

Vardopoulos, Ioannis. "Critical Sustainable Development Factors in the Adaptive Reuse of Urban İndustrial Buildings: A fuzzy DEMATEL Approach.” Sustainable Cities and Society 50 (2019): $1-12$.

World Heritage Committee (WHC). "State of Conservation of World Heritage Properties," Decision: 39 COM 7. Bonn: 39th session of the World Heritage Committee, 2015, 10-53.

World Heritage Committee (WHC). Operational Guidelines for the Implementation of the World Heritage Convention. Paris: UNESCO World Heritage Centre, 2019.

Yarlıgaş, Vildan. “Almanya'da Mimari Rekonstrüksiyona Bakış: Üç Dönem, Üç Örnek.” Mimarist 60 (2017): 38-45.

Yaş, Hakan ve Can Çetin. "Edirne'nin Kentsel Genişlemesinin İmar Planları üzerinden İncelenmesi," Kentleşme ve Yerelleşme Sürecinde Edirne Monografisi. Edited by Mahmut Güler and Seyhan Güler. İstanbul: Marmara Belediyeler Birliği Kültür Yayınları, 2019, 107-148. 
